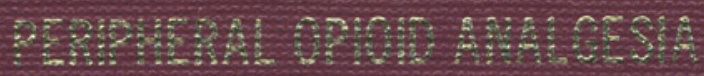

1900

FIII): 


\section{UNIFORMED SERVICES UNIVERSITY OF THE HEALTH SCIENCES \\ F. EDWARD HEBERT SCHOOL OF MEDICINE \\ 4301 JONES BRIDGE ROAD \\ BETHESDA, MARYLAND 20814-4799}

\section{APPROVAL SHEET}

Title of Thesis: "Peripheral Opioid Analgesia"

Name of Candidate: Mary Cranford Figliola

Neuroscience Program

Master of Science

July 1999

Thesis and Abstract Approved:

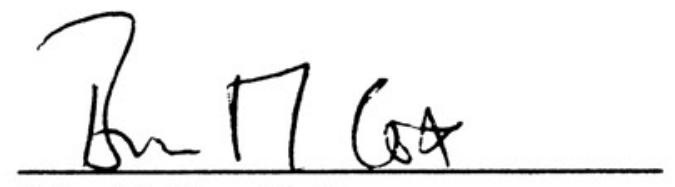

Brian M. Cox, Ph.D.

Department of Pharmacology

Thesis Advisor

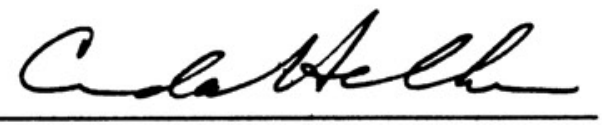

Cinda Helke, Ph.D.

Neuroscience Program Director

Committee Member

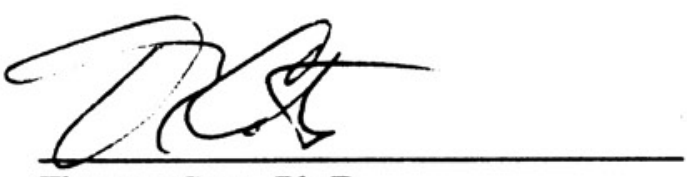

Thomas Cote, Ph.D.

Department of Pharmacology

Committee Member

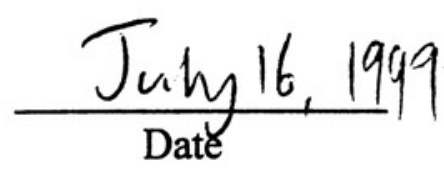

$\frac{\text { Guly } 44+929}{\text { Date }}$

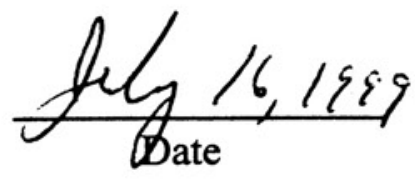


The author hereby certifies that the use of any copyrighted material in the dissertation entitled:

\section{"Peripheral Opioid Analgesia"}

beyond brief excerpts is with the permission of the copyright owner, and will save and hold harmless the Uniformed Services University of the Health Sciences from any damage which may arise from such copyright violations.

$$
\text { Manf Cranford tiglula }
$$




\begin{abstract}
Peripheral Opioid Analgesia

Mary Cranford Figliola, Master of Science, 1999

Thesis directed by Brian M. Cox, Ph.D, Chairman, Department of Pharmacology

Exogenous and endogenous opioid compounds are known to have analgesic effects. Endogenous opioid compounds include endorphin, enkephalin and dynorphin which are differentially processed from precursor peptides depending on the site of their production. These peptides exert their effects through at least three opioid receptors: mu, delta and kappa. Exogenous opioid compounds can exert a more potent analgesic action but are accompanied by deleterious side effects including respiratory depression and addiction. These side effects are centrally mediated and until recently the analgesic actions of opioids were believed to occur in the CNS as well. Recent laboratory and clinical studies indicate that in the presence of inflammation endogenous and exogenous opioids have analgesic effects in the periphery. Certain immune factors are involved resulting in increased endogenous opioid peptides at the site of injury and resulting in increased opioid receptors at the nerve terminal allowing for peripheral opioid analgesia.
\end{abstract}




\title{
PERIPHERAL OPIOID ANALGESIA
}

\author{
by \\ Mary Cranford Figliola
}

Thesis submitted to the Faculty of the Neuroscience Program of the Uniformed University of the Health Sciences in partial fulfillment of the requirements for the degree of Master of Science 1999. 


\section{Table of Contents}

Page numbers

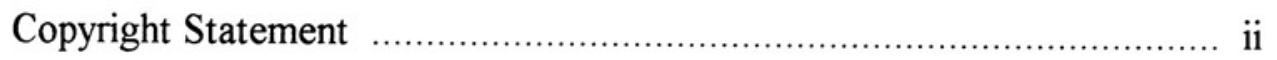

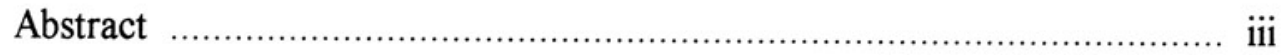

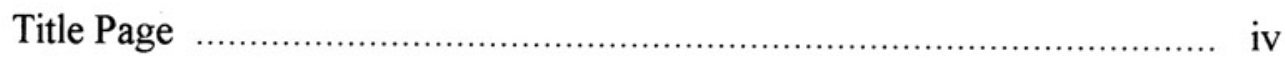

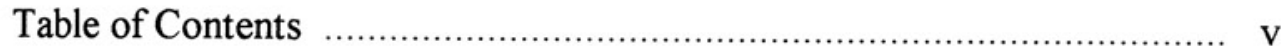

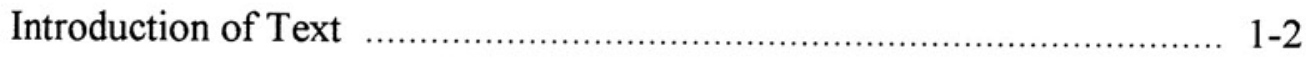

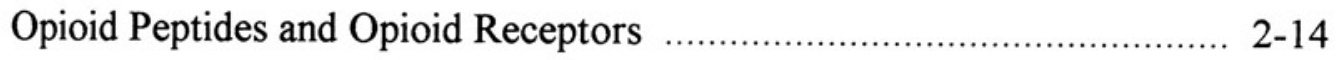

Pain Pathways and Central Opioid Analgesia ..................................... 15-19

Peripheral Antinociceptive Effects of Opioids ................................ 20-55

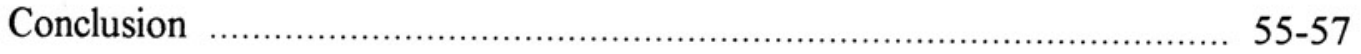

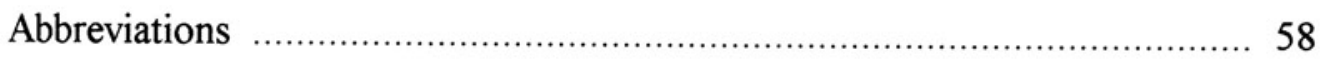

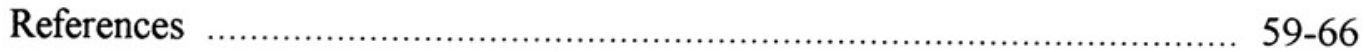


A central aspect of medical history has focused on the alleviation of pain. As time has passed, scientists and physicians have acquired a better understanding of the generation of noxious stimuli as well as the propagation and modulation of noxious signaling. This knowledge has led to the generation and use of local anesthetics which act in the periphery to ameliorate pain by blocking the transduction of noxious stimuli to the central nervous system (CNS). However, these agents remove all sensation, and induce motor paralysis. Furthermore, the potency and longevity of these agents has not always been adequate. It has become a common practice to include opioids in these local anesthetics. It was initially believed that the enhanced analgesia obtained by including opioids was due to their uptake from the periphery to the central nervous system. However, recent research into this field has indicated a therapeutic target in the periphery at the injury site. Research suggests that this peripheral antinociceptive effect involves an interaction between opioids and local inflammatory agents, including cytokines, in the environment of peripheral pain-sensitive nerve endings. A better understanding of the complex interactions among these molecules and in particular the regulation of opioid peptide and opioid receptor expression and function in the periphery should lead to better pain management therapies.

This thesis will review what is known about opioid peptides and opioid receptors. Factors regulating the biosynthesis and processing of opioid peptides and receptors will also be discussed. The structure and function of primary afferent neurons, and in particular their role in the generation, propagation and modulation of noxious stimulation 
will be summarized. The final section of this thesis will review the possible nociceptive roles played by opioid peptides and opioid receptors in the periphery.

\section{OPIOID PEPTIDES AND OPIOID RECEPTORS}

\section{Endogenous Opioid Peptides}

"Opioid" refers to a group of drugs, both natural and synthetic, which act similarly to morphine (opioid receptor agonist). Opiate drugs are plant products and their synthetic congeners derived from heterocyclic products of the opium poppy. Endogenous opioids are peptides that mimic some or all of the actions of opiate drugs, and in some cases produce additional actions. Opiate drugs are used therapeutically mainly as analgesics, but they are used for other medicinal purposes including anesthesia, symptomatic relief of diarrhea and dysentery, and cough suppression. Opioids have addictive properties and tolerance to these drugs is established if they are used continuously especially in otherwise healthy individuals. The use of opium as a euphoriant began as early as the third millennium B.C.; opium abuse and addiction date back as far as well. Morphine was isolated in 1806 and as early as 1850 it was used medicinally in conjunction with anesthesia, and it continues to be used for pain relief. Because of its addiction and abuse potential, investigators in the 1900 's began looking for a less addicting but equally potent opiate (Brownstein, 1993). Research in this field has intensified over the last several 
decades to not only identify a safer drug but also to gain an in depth understanding of opioid action and opioid receptor action from a molecular level to a behavioral level.

During the 1970's the three best known opioid peptides (enkephalin, endorphin and dynorphin) were isolated and identified (Evans et al., 1988). Subsequent to the discovery of all three opioid peptides, efforts were made by several groups to identify the genes encoding the peptides and to understand the expression of these genes.

Proopiomelanocortin (POMC) is the precursor peptide which contains $\beta$-endorphin; proenkephalin is the precursor peptide which contains methionine-enkephalin (Metenkephalin) and leucine-enkephalin (Leu-enkephalin); and prodynorphin is the precursor peptide for dynorphin A and dynorphin B. The expression and processing of each opioid peptide is discussed below.

The human POMC gene is 7665 base pairs (bp) long which contains three exons and two introns. Once transcribed, the POMC messenger RNA (mRNA) found in the pituitary is approximately 1200 nucleotides. Shorter POMC transcripts have been found in peripheral tissues. The major site of POMC gene expression is the pituitary but cells in the arcuate nucleus of the hypothalamus and some peripheral tissue such as lymphocytes and the gonads also express POMC. Studies suggest that the expression of POMC in the anterior pituitary is under negative feedback control by adrenal steroids but under positive control by corticotropin releasing hormone (CRH). Interleukin- $1 \alpha$ and interleukin- $1 \beta$ and morphine stimulate POMC expression which is probably mediated through $\mathrm{CRH}$. In the periphery of humans, rats and cows the POMC mRNA is $200-300$ base pairs smaller than 
that found in the hypothalamus and pituitary. These shorter POMC mRNAs are not as efficiently translated due to the absence of the signal sequence (Hollt, 1993).

The translation of POMC mRNA in the pituitary results in a 31 kdalton glycoprotein referred to as POMC. This glycoprotein is the precursor for $\beta$-lipotropin ( $\beta$ $\mathrm{LPH}), \gamma$-LPH, adrenocorticotrophic hormone (ACTH), $\gamma$-melanocyte-stimulating hormone $(\gamma$-MSH), $\alpha$-MSH, $\beta$-endorphin, and $\alpha-\mathrm{MSH})$. The major bioactive peptides resulting from POMC are flanked by pairs of basic residues at both the C-terminal and the $\mathrm{N}$ terminal. $\beta$-endorphin and ACTH contain internal basic residues allowing for further enzymatic cleavage. Studies on primary pituitary cell culture indicate that the processing pathway is initiated by an enzymatic cleavage at the C-terminal of ACTH giving rise to $\beta$ LPH which is a nonopioid fragment containing $\beta$-endorphin (Figure 1). Subsequent cleavage gives rise to $\mathrm{ACTH}$ and $\beta$-endorphin. These peptides can be further processed to give rise to $\alpha-\mathrm{MSH}$ and smaller endorphins. This processing pathway is by no means the only way POMC can be processed; differential processing can occur in different tissues allowing for variation in the peptide products (Evans et al., 1988).

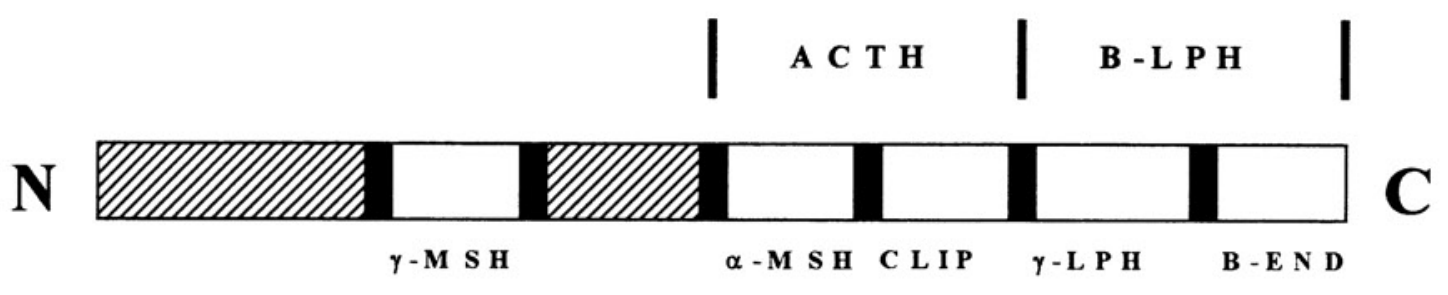

Figure 1: Schematic of the glycoprotein POMC. Dark areas indicate possible dibasic cleavage sites; clear areas indicate possible cleavage products (redrawn from Scheller and Hall, 1992). 
Proenkephalin contains 267 amino acids and gives rise to four copies of Metenkephalin, one copy of Leu-enkephalin, one copy of the octapeptide Met-enkephalinArg-Gly-(or Ser)-Leu and one copy ot the heptapeptide Met-enkephalin-Arg-Phe. Differential posttranslational processing can give rise to larger enkephalin-containing peptides. The gene for proenkephalin in humans is approximately 5200 base pairs long and is located on chromosome 12. It gives rise to proenkephalin mRNA in the brain and adrenal medulla of about 1400 nucleotides. The striatum of the brain contains the highest levels of proenkephalin mRNA where expression of the proenkephalin gene seems to be under negative control by dopamine. In the ventromedial hypothalmus, where proenkephalin mRNA is also found, gene expression may be positively controlled by estrogen and progesterone. Other areas in the central nervous system where proenkephalin mRNA is found are the hippocampus, cortex, pituitary, spinal cord and lower brainstem. In the spinal cord, especially in lamina I and lamina II increases in proenkephalin mRNA have been found in response to inflammatory stimuli especially in lamina I and lamina II. In the periphery, proenkephalin mRNA has been found in the adrenal medulla. Morphine, in vivo, and 8-bromo-cAMP and depolarizing stimuli in primary adrenal cultures, increase the levels proenkephalin mRNA. Proenkephalin mRNA has also been found in the ventricles of the heart as well as the gonads. Various immune cells, including T-helper cells, also contain mRNA for proenkephalin (Hollt, 1993). Again, posttranslational processing occurs where two basic amino acids are found; these amino acids are either lysine or arginine or one of each. The precursor proenkephalin 
peptide can be processed to give rise to different proteins in different tissues according to which enzymes are contained in that tissue (Evans et al., 1988).

Dynorphin A (DYN) and dynorphin B (DYN B) are derived from the precursor protein prodynorphin (PDYN). Prodynorphin is 254 amino acids long and also gives rise to Leu-enkephalin, and $\alpha$ - and $\beta$-neoendorphin. In pigs, prodynorphin mRNA in the brain is approximately 3200 nucleotides; smaller mRNAs have been found in the adrenal gland (Hollt, 1993). Posttranslational cleavage sites are again at dibasic sites; the initial cleavage gives rise to $\alpha$-neoendorphin and dynorphin 32. Subsequent cleavage of $\alpha$-neoendorphin gives rise to $\beta$-neoendorphin which in turn can be cleaved to generate Leu-enkephalin. Cleavage of dynorphin 32 gives rise to dynorphin 1-17 (or dynorphin A) and dynorphin B 29. Dynorphin A can be cleaved to give rise to dynorphin 1-8 which can be further cleaved to give rise to Leu-enkephalin. Cleavage of Dynorphin B 29 generates dynorphin B and further cleavage of dynorphin B gives rise to another copy of Leu-enkephalin (Evans et al., 1988). Prodynorphin mRNA is found in the magnocellular divisions of the supraoptic and paraventricular nuclei in the hypothalamus. Dehydration results in a marked increase in prodynorphin mRNA in these areas. Other regions of the CNS where prodynorphin mRNA has been found include the hippocampus, spinal cord, and pituitary. In the spinal cord, acute or chronic inflammation enhances the production of prodynorphin mRNA as well as the derived peptides. Prodynorphin mRNA in the periphery has been found in the heart ventricle, adrenal gland and gonads (Hollt, 1993). 


\section{Opioid Receptors}

As previously mentioned, as early as the first decade of this century a paramount effort was made to synthesize or identify effective analgesics that were less addicting than morphine. The pharmacology of these drugs was studied and it was realized that there were very specific structural requirements for the analgesic effect of opioids. A.H. Beckett noted that the D-(-)-isomer had more potent analgesic activity than the L-(+)isomer for a number of opioid substances. He ruled out that this difference in activity was due to a difference in absorbance or metabolism. He proposed that the importance of stereospecificity for activity was due to the interaction of the drug with a receptor. Quite ingeniously, he studied the common features of the analgesic agents and further proposed essential characteristics of the receptor as well as proposing how the drug and receptor would interact (Beckett and Casy, 1954).

However, it was not until 1973 that this postulate was confirmed by Simon et al. (1973), Pert and Snyder (1973), and Terenius (1973) using a theoretical approach developed by Goldstein et al. (1971). The major challenge in directly demonstrating the binding of a drug to a receptor is the discrimination of binding to the receptor and binding to other sites. Goldstein et al. (1971) showed that the two kinds of binding could be discriminated by the use of a drug existing in two enantiomeric forms, only one of which binds to the receptor. In Pert and Snyder's study, brain homogenates were incubated with [-] $\left[{ }^{3} \mathrm{H}\right]$-naloxone (opioid receptor antagonist) and either levorphanol (a levorotatory isomer of a morphine-like drug; the D-(-)-isomer) or dextrorphan (a dextro- 
rotatory isomer of a morphine-like drug; the L-(+)-isomer). In this study, only levorphanol influenced the binding of ${ }^{3} \mathrm{H}$-naloxone indicating there must be a receptor present for this stereospecific binding. Brain and guinea pig ileum, the contractions of which are inhibited in the presence of opiates, were then incubated with varying concentrations of different drugs. ${ }^{3} \mathrm{H}$-naloxone was added and the $\mathrm{ED}_{50}$, an indication of affinity, for each drug was determined. These affinities corresponded closely to the pharmacological activity of each drug indicating again that the ligands must be binding to a specific site. In comparing the drug studies in brain homogenates and guinea pig ileum there was some variation in potency. This finding lent credence to the possible existence of more than one type of opioid receptor.

Martin et al. (1976) provided conclusive evidence for multiple opioid receptors in their study of the "chronic spinal dog". The "chronic spinal dog" was an experimental model used to examine physical dependence on opioid, and other, analgesics. Surgical transections of these dogs' spinal cords were made at approximately the 10th thoracic level. A quantitative and qualitative evaluation of the drugs' actions could be made because the drugs' actions on the effector systems innervated by portions of the nervous system below and above the level of the transection could be studied together (Martin et al., 1964). Their work was based on the knowledge from previous studies that morphine and morphine-like substances cause physiological and behavioral changes in dogs and other animals, and that these changes were not identical for all of the opioid substances. The chronic spinal dog was used to provide physiological and behavioral data which yielded potency estimates for various putative agonists, antagonists and partial agonist. 
The authors established a valid means of measuring and weighting various responses and they also developed a valid protocol to assess cross-tolerance. That is, they looked at the potency of drugs to suppress abstinence in the abstinent dependent chronic spinal dog and at the potency of drugs to precipitate the abstinence syndrome in the established dependent chronic spinal dog. Initially the authors characterized the physiological and behavioral responses to various drugs in nondependent animals. They then looked at some of these drugs' ability to precipitate abstinence in the dependent dog. Based on the results of these studies, the authors suggested that in addition to the opioid receptor which binds morphine the most readily, the mu receptor, there existed a receptor that interacted more readily with ketocyclazocine and cyclazocine (kappa receptor agonists), the kappa receptor. In addition, another receptor type, called sigma, was proposed as being responsible for mediating the effects of SKF-10,047 (N-allylnormetazocine). This study did not evaluate the receptor types utilized by endogenous ligands for opioid receptors nor did the study assess actual binding and correlate it to pharmacological responses (Martin et al., 1976).

Differentiation of opioid receptors based on these types of studies was performed by Lord et al. (1977). Inhibition of contraction of guinea pig ileum and mouse vas deferens was used in the in vitro study where the rank order of potency was established for various agonists. The relative potencies for morphine and other opioid agonists using competitive binding assays was established and the results suggested that more than one type of opioid receptor existed. $\mathrm{ID}_{50}$ values for endogenous opioid peptides were then found in the two tissue types. The $\mathrm{ID}_{50}$ value for $\beta$-endorphin (mu and delta opioid 
receptor agonist) was similar in both tissue types; however, the $\mathrm{ID}_{50}$ values of $\alpha$ endorphin, Met-enkephalin (mu and delta opioid receptor agonist), and Leu-enkephalin (delta opioid receptor agonist) were very different. These three peptides are more potent in the vas deferens than in the ileum. The $\mathrm{ID}_{50}$ for morphine was also determined in this study, and it was found that the guinea pig ileum was much more sensitive to morphine than the mouse vas deferens. From this evidence it seemed clear that the receptor population in the two tissues differed. Inhibition of binding by the radiolabelled ligands, ${ }^{3} \mathrm{H}$-Leu-enkephalin and ${ }^{3} \mathrm{H}$-naloxone, were used to compare binding of the endogenous ligands in guinea pig brain homogenates. The inhibition of binding results were then compared to the pharmacological potency results found in the guinea pig ileum and the mouse vas deferens. The pharmacological activity of the peptides in the guinea pig ileum correlate well with the inhibition of binding of ${ }^{3} \mathrm{H}$-Leu-enkephalin. Furthermore, $\mathrm{Mr} 2266$ (kappa opioid receptor antagonist) and naloxone antagonist activity in the presence of enkephalins, normorphine and benzomorphans (kappa opioid receptor agonist and weak mu opioid receptor antagonist) was studied in the ileum and vas deferens. The results from this study as well as from those mentioned above indicated that the receptor population differed in the two tissues. It seemed that the guinea pig ileum was composed primarily of the mu-receptor but also contained the kappa receptor whereas the mouse vas deferens contained another receptor type, the delta- receptor (Lord et al., 1977). Since these early studies establishing the existence of the mu, delta, and kappa opioid receptors, several pharmacological studies have been undertaken to determine selective agonists and antagonists for each receptor type (Figure 2). Cloning of the these three opioid receptors, 
which will be discussed below, has also indicated subtypes of these receptors and allowed for the determination of selective agonists and antagonists for some of these subtypes.

\begin{tabular}{|c|c|c|c|}
\hline Recoptor & Solective dophlst & Seloctive Antogonist & $\begin{array}{l}\text { Potencles of } \\
\text { Endogenous tigand }\end{array}$ \\
\hline Delta $(\delta)$ & $\begin{array}{l}\text { DSBULET } \\
{\left[\mathrm{D}-\mathrm{Ala}^{2}\right] \text { deltorphin I or II }}\end{array}$ & $\begin{array}{l}\text { Naltrindole } \\
\text { ICI174864 } \\
\text { TIPP }\end{array}$ & $\begin{array}{l}\text { B-end }=\text { leu-NK = met- } \\
\text { ENK }>\text { dyn A }\end{array}$ \\
\hline Kappa (к) & $\begin{array}{l}\text { CI977 } \\
\text { U69593 } \\
\text { U50488 }\end{array}$ & nor-binaltorphimine & $\begin{array}{l}\text { dyn } \mathrm{A} \gg \mathrm{B} \text {-end }>\text { leu - } \\
\text { ENK = met-ENK }\end{array}$ \\
\hline $\mathrm{Mu}(\mu)$ & $\begin{array}{l}\text { DAMGO } \\
\text { PL017 } \\
\text { Morphine } \\
\text { Sufentanil }\end{array}$ & $\begin{array}{l}\text { CTOP } \\
\text { CTAP }\end{array}$ & $\begin{array}{l}\text { B-end }>\text { dyn A }>\text { met - } \\
\text { ENK }>\text { leu-ENK }\end{array}$ \\
\hline
\end{tabular}

Figure 2: Pharmacology of opioid receptors and the relative potencies of endogenous ligands.

\section{Signal Tranduction Pathways Activated by Opioid Receptors}

Subsequent to identifying opioid receptor types, studies have been ongoing to determine how the activation of opioid receptors generates a response on a cellular level. Collier and Roy, in 1974, demonstrated that in brain homogenates binding of opioid agonists caused a decrease in prostaglandin stimulated increase in adenylate cyclase activity. This finding was of particular importance as prostaglandin elicits hyperalgesia, cough, and diarrhea, all of which are treated with opiates (Collier and Roy, 1974). Thus, it was felt that this coupling to adenylate cyclase might hold the key to understanding morphine's analgesic effects. Since this initial study sufficient data has been gathered indicating that all three opioid receptor types are coupled to G-proteins (Childers, 1991). 
These data includes: 1.) receptor binding regulation by guanine nucleotides for agonists and antagonists and is sodium dependent 2.) opioid-stimulated GTPase activity and 3.) adenylate cyclase inhibition which is reversed in the presence of pertussis toxin and is GTP-dependent (Childers, 1991). Studies utilizing both brain homogenates and transformed cells such as NG108-15 cells have been key in establishing the coupling of $\mathrm{G}_{\mathrm{i}}$ to all three opioid receptors. Binding of an agonist to the receptor activates $\mathrm{G}_{\mathrm{i}}$ which in turn inhibits the second messenger adenylate cyclase thus decreasing the concentration of cAMP in the cell. The decrease in cAMP causes a decrease in the activation of cAMPdependent protein kinase. However, the protein or proteins that are affected by this inhibition of phosphorylation have yet to be identified (Childers, 1988).

Not only has it been shown that all types of opioid receptors inhibit adenylate cyclase, they also can activate inwardly rectifying $\mathrm{K}^{+}$channels and decrease the conductance of voltage gated $\mathrm{Ca}^{++}$channels. Pharmacological studies first indicated the coupling of the activation of opioid receptors to ion channels via G-proteins. North et al. in 1987 gathered data that mu and delta opioid receptors were coupled to an inwardly rectifying $\mathrm{K}^{+}$channel via a guanine nucleotide-binding protein (North et al., 1987). Gross et al. (1990) conducted a study suggesting the kappa selective agonist dynorphin A reduced neuronal voltage dependent $\mathrm{Ca}^{++}$currents and inhibited neuronal adenylate cyclase. Pertussis toxin inhibited these responses indicating the involvement of either $\mathrm{G}_{\mathrm{i}}$ or $\mathrm{G}_{0}$. (Gross et al., 1990). The cloning of all three classes of opioid receptors (discussed below) has allowed for more extensive studies of signaling mechanisms using homologous populations of the cloned receptors and their coupling to a specific effector through 
recombinant systems. These studies support the coupling of all three opioid receptors to a inwardly rectifying $\mathrm{K}^{+}$channel via either $\mathrm{G}_{i}$ or $\mathrm{G}_{\mathrm{o}}$ and support the coupling of kappa and mu receptors to voltage-sensitve $\mathrm{Ca}^{++}$channels via $\mathrm{G}_{\mathrm{i}}$ and $\mathrm{G}_{\mathrm{o}}$ (Kieffer, 1995).

\section{Cloning of Opioid Receptors}

Purification of opioid receptors was an endeavor undertaken by many laboratories. Purification was desirable as pertinent information about binding domains, attachment of fats and carbohydrates, functional domains, and a myriad of other information could be obtained. However, the opioid receptors proved to be difficult to isolate and purify for a number of reasons. Their presence represents a small percentage of total membrane protein. In addition, a high affinity, highly selective probe for the mRNA of these receptors had not been found. And finally, these receptors have been very difficult to solubilize and still maintain their binding ability (Simon and Hiller, 1988). A huge hurdle was overcome when Evans et al. (1992) cloned the delta receptor. Because no definitive amino acid sequence of the receptor had been obtained, they did not use a degenerative probe but instead prepared a cDNA library from NG-108 cells for expression cloning. The cDNA was transfected into COS cells and the cells were screened for binding to radiolabelled DADLE (delta opioid receptor agonist). Positive colonies were purified and transfected until one cDNA (DOR-1) was isolated. DOR-1 was expressed in COS cells and competition studies were performed which revealed highly specific binding of deltaspecific peptides and alkaloids. To ensure that the cDNA product expressed a protein 
which functioned as an opioid receptor might, the investigators measured the effect of DPDPE (delta opioid receptor agonist) on forskolin induced accumulation of cAMP. They found a considerable decrease in cAMP levels as would be expected. After sequencing the protein, they looked for amino acids and domains that had been predicted for the opioid receptor considering binding, function, and putative homology to other receptor proteins. Much of what they found correlated with what was expected. It was not long after the cloning of the delta receptor that Yasuda et al. (1993) cloned the kappa receptor and Chen et al. (1993) cloned the mu receptor. The cloning of all three receptor classes has allowed for structural and functional characterizations that were not possible before. It is now recognized that the three opioid receptors are a receptor family encoded by three homologous genes. All three receptors have been cloned in mice, rats and humans, and they show high homology among species. Although pharmacological studies suggests two subtypes of delta receptors, two subtypes of mu receptors and three subtypes of kappa receptors, only one of each receptor type has been cloned to date. Based on the data from cloning, the deduced amino acid sequence for the three opioid receptors indicate that they have 7 transmembrane domains which is characteristic of other G-protein coupled-receptors And finally, the cloning of the opioid receptors has allowed for more comprehensive binding studies. Studies of chimeric receptors has lead to a better understanding of receptor selectivity and other ligand-receptor interactions. (Kieffer, 1995). 


\section{PAIN PATHWAYS AND OPIOID ANALGESIA}

\section{Peripheral Nociceptive Signaling}

Signals generated by potentially damaging insults to the body are transmitted from peripheral sites to the central nervous system by neurons called primary afferent nociceptors (PANs). These neurons have their cell bodies in the dorsal root ganglia (DRG). They are bipolar neurons with a peripheral process which initiates noxious signaling and a central process which synapses with neurons in CNS, specifically in the spinal trigeminal nucleus, a region in the dorsal horn of the spinal cord. PAN's are not simple relay mechanisms; rather, plasticity of these neurons plays a role in the variation of nociceptive responses both in the short term and the long term (Levine et al., 1993). Primary afferent nociceptors are believed to be composed of two types of nerve fibers: Cfibers and A $\delta$-fibers. Both types of fibers have free nerve endings in the periphery and can either respond to one type of noxious stimulus or to two or three modalities (polymodal receptors). A $\delta$-fibers are thinly myelinated fibers whereas $\mathrm{C}$-fibers are unmyelinated. $\mathrm{A} \delta$ fibers are responsible for the immediate pain one would feel while touching a hot stove while C-fibers are responsible for the dull ache felt afterward (Shepherd, 1988).

Several endogenous substances are known to activate PANs in a region receiving a noxious insult. These substances include serotonin, bradykinin, and histamine. Serotonin (5-hydroxytryptamine [5-HT]) is derived from platelets in the region and it is believed to activate PANs via 5- $\mathrm{HT}_{3}$ receptors (Rueff and Dray, 1992). Bradykinin is produced from 
blood proteins and its effects occur through two known bradykinin receptors, $\mathrm{B}_{1}$ and $\mathrm{B}_{2}$. $B_{1}$ receptors play a role in hyperalgesia, their presence being sparse until inflammatory conditions stimulate their expression. In addition, the $\mathrm{B}_{1}$ receptors have a greater affinity for the metabolite of bradykinin, des-Arg'-bradykinin (Steranka et al., 1988). Sensory neurons contain $\mathrm{B}_{2}$ receptors which are coupled to a G-protein. When these are activated they stimulate the formation of the second messengers, diacylglycerol (DAG) and 1,4,5inositol-trisphosphate $\left(\mathrm{IP}_{3}\right)$, through the activation of phospholipase $\mathrm{C} . \mathrm{IP}_{3}$ accumulation results in intracellular calcium release (Thayer et al., 1988) while DAG induces protein kinase $\mathrm{C}$ activation resulting in the phosphorylation of certain receptors and ion channels, including $\mathrm{Na}^{+}$ion channels. This action causes the opening of the $\mathrm{Na}^{+}$channel resulting in depolarization of the membrane which, in turn, results in $\mathrm{Ca}^{++}$influx (Shearman et al., 1989). The increased intracellular $\mathrm{Ca}^{++}$concentration, from both intracellular and extracellular sources, causes the release of various neuropeptides, including substance $P$, and causes the formation of arachidonic acid as a result of phospholipase $\mathrm{C}$ activation (Allen et al., 1992). Mast cell degranulation, caused by certain mediators of inflammation such as interleukin-1 $\beta(\mathrm{IL}-1 \beta)$ and substance $\mathrm{P}$, releases histamine which increases $\mathrm{Ca}^{++}$ permeability resulting in the release of certain neuropeptides (Falus and Meretey, 1992).

Sensitization, which is a long-term increase in neuronal excitability, occurs in PANs in response to constant stimulation. Sensitization includes a lowered activation threshold, prolonged firing in response to a suprathreshold stimulus, and more spontaneous neuronal activity. Sensitization of PANs is partially responsible for hyperalgesia, a lowered threshold for pain (Levine et al., 1993). Certain endogenous 
substances are capable of sensitizing PANs; these substance include $\mathrm{PGE}_{2}, 5-\mathrm{HT}, \mathrm{IL}-1 \beta$ and bradykinin. Prostaglandin $\mathrm{E}_{2}\left(\mathrm{PGE}_{2}\right)$ causes a $\mathrm{Na}^{+}$induced depolarizing current and a subsequent release of certain neurotransmitters (Puttick, 1992). 5-HT, activating 5-HT 1 and $5-\mathrm{HT}_{2}$ receptors, sensitizes by reducing the threshold for activation by other noxious stimuli (Taiwo and Levine, 1992). Bradykinin indirectly sensitizes PANs by causing the release of $\mathrm{PGE}_{2}$ (Allen, 1992). IL-1 $\beta$, which is produced by leukocytes, sensitizes PANs by an unknown mechanism which may be $\mathrm{PGE}_{2}$ dependent (Schweizer, 1988). It is clear that there is an intricate interaction of molecules on PAN's as well as other cells which results in initiating nociception and in lowering the PAN's threshold for extended periods of time. The exact mechanism whereby these agents cause sensitization and other longterm effects such as the regulation of gene expression is poorly understood at this time. However, it is known that c-fos, an immediate early gene, mRNA is increased in the dorsal horn of the spinal cord subsequent to various types of peripheral tissue insult. The increased transcription of c-fos is calcium dependent and distinct signaling pathways, dependent on the mode of $\mathrm{Ca}^{++}$increase, induce the transcription (Ghosh et al., 1994). Since some of the above mentioned sensory activators induce an increase intracellular $\mathrm{Ca}^{++}$ concentration it is possible they may be influencing the transcription of certain proteins in primary afferent neurons. 


\section{Central Pain Pathways}

PAN terminate in the spinal cord resulting in a reflex action or in a relay action to the brain. The dorsal horn is arranged in six layers; C-fibers terminate mainly in layer II, the substantia gelatinosa and $\mathrm{A} \delta$-fibers terminate mainly in layer I, the marginal layer. These fibers can terminate on more than one neuron in the dorsal horn. In addition, it is important to realize that there are also microcircuits within the dorsal horn relaying information to other areas of the spinal cord. There are two ascending pathways relaying nociceptive information. One pathway arises from the cells of the dorsal horn, crosses the midline and ascends in an anterolateral tract of the spinal cord through the brainstem terminating in the thalamus. This tract is called the spinothalamic pathway and the majority of sensations its fibers mediate are temperature and pain although there are some fibers conveying joint and tactile information. In addition, collaterals from this tract terminate in the reticular formation; these neurons act as an ascending polysynaptic system which feeds into the thalamus as part of the ascending reticular formation. This ascending tract is involved in consciousness and arousal (Shepherd, 1988).

It is known that certain areas, the posterior nuclei and the ventrobasal complex, of the thalamus respond to noxious stimulus. The thalamus does project somatosensory data to the cortex and activation of primary and secondary somatosensory cortex has been shown in response to noxious stimulation, but the exact role the cortex plays in pain sensation has not been determined (Guilbaud et al., 1994). 


\section{Central Opioid Analgesia}

Spinothalamic tract collaterals project to the brainstem activating descending analgesic systems (Le Bars and Villanueva, 1988). These supraspinal descending analgesic systems originate in very specific brainstem structures including locus ceruleus, the periaquaductal grey matter and various nuclei in the medulla which in turn activate the spinal analgesic system. Activation of the supraspinal mechanism can involve three analgesia inducing systems: the opioid system (release of endorphins), the serotonergic system (release of serotonin) and the adrenergic system (release of norepinephrine). Only the opioid system will be discussed here. In this system, activation spinally or supraspinally can induce analgesia.

The first site in the CNS where transmission in nociceptive pathways can be modified is the first synapse in the dorsal horn of the spinal cord. There are enkephalinergic neurons in the dorsal horn which can release enkephalin. The interaction of enkephalin with opioid receptors on primary afferent neurons hyperpolarizes the neuron, thus inhibits the increase in the intracellular $\mathrm{Ca}^{++}$concentration. Without a high concentration of $\mathrm{Ca}^{++}$, substance $\mathrm{P}$, a neurotransmitter of pain, cannot be mobilized and released. Enkephalin can also act on the terminals of ascending pain neurons, hyperpolorizing them, and thus making it more difficult for the transmission of the pain signal (Basbaum and Fields, 1984).

Supraspinal sites of opioid analgesia include the locus ceruleus (LC), which is found in the dorsal brainstem, the periaqueductal gray matter (PAG), which is found in the 
upper brainstem, and certain nuclei found in the medulla, the nucleus raphe magnus $(\mathrm{NRM})$ and the nucleus reticularis gigantocellularis (NRGC). Signals from the thalamus, hypothalamus, frontal cortex, amygdala, and the ascending spinothalamis tract can project to the PAG. Transmission neurons project from the PAG mainly to the NRM and hence to the spinal cord while some project to the LC. Research suggests activation of mu opioid receptors by $\beta$-endorphin or enkephalin in the PAG causes analgesia by hyperpolarizing GABA neurons there allowing for signal transmission to the NRM (Bodnar et al., 1988). Subsequently, serotonergic neurons in the NRM synapse in the dorsal horn where it is believed they inhibit the transmission of pain. Activation of mu opioid receptors in the NRM also inhibit GABAergic neurons allowing for the same serotonergic mechanism to induce analgesia in the dorsal horn. In the LC, activation of $\mathrm{mu}$ opioid receptors hyperpolarizes neurons thus decreasing adrenergic projections to the NRM resulting in less GABA inhibition (Lipp, 1991). Obviously, opioid analgesia is much more complicated than is described here but this summary outlines some of the suggested mechanisms of opioid analgesia.

\section{PERIPHERAL ANTINOCICEPTIVE EFFECTS OF OPIOIDS}

\section{Effects of Exogenously Administered Opioids}

It has long been assumed that the analgesic actions of systemically administered opiate drugs are induced through actions at sites in the CNS (Carroll and Lim, 1960). 
However, the notion that opioids can exert a peripheral analgesic effect was suggested as early as 1885 when Woods reported the treatment of neuralgias by direct application of opiates to painful areas (cited by Stein, C., 1993). It wasn't until almost a century later that the notion of peripheral analgesic actions of opioids was further investigated. Using intraplantar (i.pl.) injections of prostaglandin $E_{2}$, Ferreira and Nakamura (1979) induced inflammation in the test paw and used the contralateral paw as the control. Inflammation is characterized by hyperalgesia which is manifested as a reduction in reaction time in response to increasing pressure applied to the paw. Hyperalgesia was reduced in response to morphine, Leu-enkephalin and Met-enkephalin injected directly into the test paw, but there was no change in reaction time in the contralateral, untreated paw. The latter result indicated that the antinociceptive effect of these opioids was a local effect and not a central effect. However, naloxone failed to antagonize these effects and surprisingly had an antinociceptive effect, thus, leaving doubt as to whether the opioids' antinociceptive effects were being mediated by opioid receptors.

Subsequent studies attempted to elucidate the mechanism of the antinociceptive effects of opioids and to demonstrate that these effects were local and not central. The use of lipophobic analogs of active drugs can aid in ascertaining the site of action of these drugs since lipophobic agents do not diffuse rapidly through tissue and are not readily able to cross the blood-brain barrier. The opioid agonists and antagonists that have been used in these studies are either quaternary alkaloids or polar peptides. However, one must keep in mind that there is some penetration of the blood-brain barrier by these agents and that quaternization to reduce lipophilicity also lowers affinity for the receptor. 
Using intraperitoneal (i.p.) acetic acid as an inflammatory agent and the writhing test (measurement of the number of abdominal constrictions) as an indicator of nociception, Smith et al. (1982) found that morphine and N-methyl morphine (quaternary alkaloid of morphine which is charged and lipophobic) induced potent analgesic actions which were both antagonized by naloxone (opioid receptor antagonist). N-methyl nalorphine (quaternary alkaloid of nalorphine which is an opioid receptor antagonist) inhibited the antinociceptive effect of N-methyl morphine but not of morphine. To further demonstrate that the effects of $\mathrm{N}$-methyl morphine were being mediated locally, Smith et al. (1982) used radioactive ligands and found minimal uptake of N-methyl morphine into the CNS. In addition, the reduced nociception produced by N-methyl morphine was only noted in the writhing test and not in the hot plate test. Morphine was effective in both tests although to a lesser degree in the hot plate test.

Other studies utilizing polar compounds have been confounding. Using carrageenan as an inflammatory agent injected into the paw, Rios and Jacob (1982) observed an analgesic effect of the opiate antagonists naloxone and $\mathrm{N}$-methyl naloxone (quaternary form of naloxone) although at low doses of naloxone, morphine was partially antagonized. N-methyl-nalorphine was also observed to have antinociceptive effects using both carrageenan and $\mathrm{PGE}_{2}$ as inflammatory agents (Ferreira et al., 1984). The agonistic actions of N-methyl-nalorphine and $\mathrm{N}$-methyl naloxone have been attributed to the formation of a morphine-like metabolite. It has also been suggested that the antagonistic actions of naloxone at low doses, with agonist actions at higher doses, might be attributed to the possibility that different types of receptors are responding in an opposing manner 
(Stein, 1993). Another criteria indicating that opioids were exerting an analgesic effect through the previously identified opioid receptors was that receptor mediated effects should to be stereospecific. Ferreira et al. (1982) demonstrated that levorphanol induced analgesia in the paw pressure test following $\mathrm{PGE}_{2}$ injection, although not as potently as morphine. The dextro-rotatory isomer, dextrorphan, had no agonist effects.

To summarize, these studies suggest that opioid agonists, including peptides, might have a peripheral analgesic effect. However, this effect is limited to reducing hyperalgesia in the paw pressure test using $\mathrm{PGE}_{2}$ and carrageenan as inflammatory agents and reducing hyperalgesia in the writhing test using acetic acid to induce abdominal inflammation. Opioid agonists had very limited or no analgesic effects in thermal stimulation tests. In addition, conflicting actions of naloxone in some studies, i.e. acting as an antagonist at low doses but as an agonist at higher doses, raise the possibility that different types of receptors may be functioning in an opposing fashion.

\section{Involvement of Opioid Receptors: Pharmacological Studies}

Several groups of investigators have attempted to clarify which type of opioid receptors are involved in peripheral opioid analgesia. Follenfant et al. (1988) demonstrated locally mediated analgesia using the delta selective, polar enkephalin analogue BW $443 \mathrm{C}$, suggesting that the endogenous ligand, enkephalin, might have local analgesic effects. Analgesia was also demonstrated using morphine in this study. Phenyl-p-benzoquinone 
(PBQ) acetic acid was used as an inflammatory agent in the writhing test, and once again the analgesic effect of the opioid agonists was more pronounced in the writhing test than in the hot plate test. The reduction in PBQ-induced responses was antagonized by $\mathrm{N}$ methyl nalorphine and naloxone and further experiments revealed more potent antagonism by i.p. injection than by intracerebroventricular injection.

The effects of delta, mu, and kappa opioid agonists were investigated by Stein et al. (1989). Using Freund's complete adjuvant injections to induce unilateral paw inflammation, opioid agonists were administered i.pl. four to six days post-inoculation. DAMGO (1 ug; mu-selective), DPDPE (40 ug; delta selective) and U-50488H (50 ug; kappa selective) induced pronounced analgesic effects in the inflamed paw during the first 30 minutes after injection. There was no effect on pain threshold in the non-inflamed paw using the same doses of these three drugs. Systemic equivalent doses administered subcutaneously (s.c.) or intravenously (i.v.) were ineffective in producing analgesia. I.pl. administration of morphine in doses between 10-100 ug were effective in a dose dependent and stereospecific manner. I.pl. administration of (-)naloxone antagonized the analgesic effects of DPDPE, DAMGO, and U-50488H in a dose dependent manner but (+)naloxone had no antagonistic effects. In addition, selective delta (ICI 174,864), mu (CTOP) and kappa (norbinaltorphimine) antagonists countered the effects of DPDPE, DAMGO, and $\mathrm{U}-50,488 \mathrm{H}$, respectively. This data further strengthens the notion that peripheral opioid analgesia can be mediated through all three types of opioid receptors.

Generally, studies using multiple agonists with varying receptor affinity have found that mu-agonists were more potent analgesic agents than delta or kappa agonists (Ferreira 
and Nakamura, 1979; Smith et al., 1982; Ferreira et al., 1982; Stein et al., 1989), except in a study by Bentley et al. (Bentley et al., 1981). Bentley found ketocyclazocine, a kappa ligand, to be a more effective analgesic agent than any other opioid agonist, but mu agonists were always more effective than delta agonists when they were compared. The stronger antinociceptive effects of mu agonists is emphasized by Levine and Taiwo (Levine and Taiwo, 1989) who showed the hyperalgesia induced by increasing amounts of $\mathrm{PGE}_{2}$ injected intradermally into rat paws was antagonized by DAMGO, morphine and morphiceptin (10 ng - $10 \mathrm{ug}$ ) but not by U50,455H, DPDPE or DSLET, at doses up to 10 ug. No change in the nociceptive threshold of normal skin was observed in response to these substances. Morphine was dose dependently inhibited by naloxone. The analgesic effect of peripherally administered morphine was inhibited by pertussis toxin which would suggest that a G-protein mechanism is mediating the analgesic effect. These findings are in line with data supporting the coupling of mu opioid receptors to $G_{i}$ as previously discussed. The doses of the kappa and delta agonists used (up to $10 \mathrm{ug}$ ) may have been too low to induce analgesia but Taiwo and Levine (Taiwo and Levine, 1991) postulated another explanation in a follow-up study. They found that although delta and kappa agonists were unable to reduce $\mathrm{PGE}_{2}$ induced hyperalgesia, they were able to block bradykinin induced hyperalgesia. They suggested that since kappa and delta opioid receptors are found on sympathetic postganglionic neurons and that bradykinin induced hyperalgesia is dependent on sympathetic postganglionic neuron terminals, the kappa and delta ligands are acting on the sympathetic terminals to reduce hyperalgesia 
Afferent discharge activity was studied to discern the role of mu, delta and kappa opioid receptors in peripheral antinociception. Russell et al. (1987) induced inflammation into the knee joints of anesthesized cats using carrageenan and kaolin administered 2 hours prior to recording spontaneous discharges from afferent neurons innervating the joints. The authors found increased discharges from the inflamed joint when compared to the contralateral non-inflamed joint and suggested that the increased activity would trigger pain sensation in an anesthesized animal. Intraarterial injections close to the knee joint of DAMGO (0.5 - $5 \mathrm{mg} / \mathrm{kg})$, morphine ( 1 - $5 \mathrm{mg} / \mathrm{kg}$ ), ethylketocyclazocine (EKC - a kappa opioid selective agonist; $0.5-4 \mathrm{mg} / \mathrm{kg})$ and $\mathrm{U}-50,488 \mathrm{H}(1-10 \mathrm{mg} / \mathrm{kg})$ inhibited the increased firing of the small diameter type IV afferents in the inflamed knee joint but induced no change in the control joint. Except for EKC, the effects of these opioid agonists were antagonized by i.a. naloxone (1 mg/kg) (Russell et al., 1987).

\section{Antinociceptive Effects of Endogenous Opioids}

The studies reviewed above indicate that opioid receptors in the periphery play an antinociceptive role upon local administration of exogenous opioids. In addition, the studies clearly reveal that the antinociceptive effect of opioids are enhanced under inflammatory conditions. The question remained as to whether endogenous opioids could elicit the same effect. Parsons et al. (1990) studied the effects of endogenously released opioids using the cold water swim (CWS) test. In this test, the test animal is placed in a container with water which stresses the animal causing the systemic release of endogenous 
opioids from the hypothalamic-pituitary-adrenal axis. Freund's complete adjuvant was used to induce hindpaw inflammation followed by subjecting the animals to CWS test for 0.5 minutes, 1 minute and 2 minutes. Upon completion of these tests, nociceptive thresholds in the inoculated paw and the control paw in response to the paw pressure tests were increased suggesting that endogenous opioids had an antinociceptive effect. The antinociception was much more pronounced in the inflamed paw than in the non-inflamed paw (Figure 3). This antinociception after the 1 minute CWS test was dose dependently antagonized by naloxone $(0.125 \mathrm{mg} / \mathrm{kg}$ s.c. $)$ and completely antagonized by naltrexone $(0.5 \mathrm{mg} / \mathrm{kg})$. Naltrexone (5 - $40 \mathrm{mg} / \mathrm{kg}$ s.c.), a quaternary agent, was also effective in antagonizing the elevated nociceptive threshold in the inflamed paw. However, the systemic (i.v.) administration of $\beta$-endorphin failed to substantially elevate the paw pressure threshold in the inflamed paw indicating that the source of endogenous opioids responsible for the enhanced antinociceptive effects might not be from the hypothalamicpituitary-adrenal axis. In addition, adrenalectomy had no effect on the stress induced antinociception in the inoculated paw. Surgical hypophysectomy abolished the stress induced antinociception following 0.5 minute and 1 minute CWS but had little effect after the 2 minute CWS. Subcutaneous injections of $300 \mu \mathrm{g} / \mathrm{kg}$ of dexamethasone (a longacting, synthetic glucocorticoid) to inhibit hypophysial corticotrophic cell secretion completely abolished the stress induced antinociception following CWS test at all time increments. These data further substantiated the notion that some other source of endogenous opioids was responsible for the enhanced antinociceptive effects. 


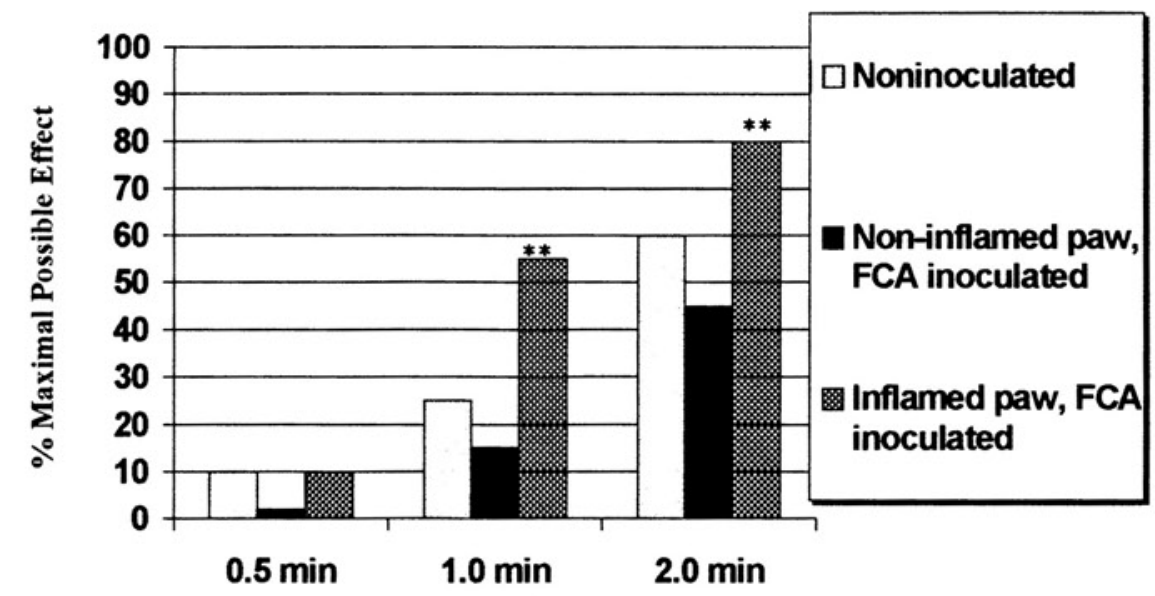

Figure 3: Paw pressure thresholds (PPT) following CWS. Mean Elevation of PPT normalized to a \% Maximal Possible Effect. (\%MPF = (post CWS PPT - basal PPT)/ ( 250 - basal PPT) X 100). Number of minutes refers to the CWS test duration. ' $\star$ ' indicates a significant difference between non-inflamed and inflamed paws. There were twelve or more observations for each treatment and the standard error for each treatment was less than $10 \%$ of the mean (redrawn from Parsons et al., 1990).

Other studies were done to determine which endogenous opioids were responsible for the antinociceptive effect and to determine their source. Stein et al. (1990) again used Freund's complete adjuvant to induce hindpaw inflammation and CWS to release endogenous stores of opioids. The authors found that 4 - 6 days post inoculation stress induced antinociception occurred following 1 minute of the CWS. This antinociception was dose dependently and stereospecifically antagonized by i.pl. but not systemic (s.c. or i.v.) administration of naloxone $(18 \mu \mathrm{g})$. Delta and $\mathrm{mu}$ selective antagonist, but not kappa selective antagonist, decreased the antinociceptive effect following the CWS indicating the involvement of the former receptors (Figure 4). 


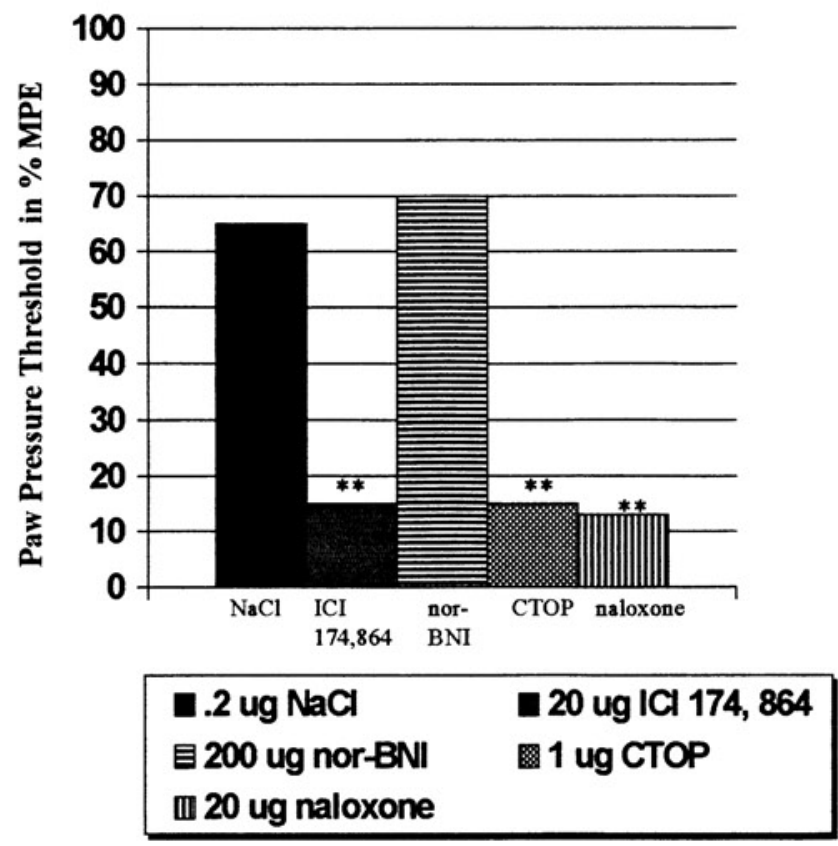

Figure 4: Effect of i.pl. (-)-naloxone and selective antagonists for $\delta$ (ICI 174, 864), $\kappa$ (nor-BNI), and $\mu$ (CTOP) receptors on Paw Pressure Threshold (PPT) elevation following 1 min CWS in inflamed hindpaw. " $* \star$ ' indicates a significant difference between stress induced PPT elevation compared to selective antagonist reduction in PPT. There were five or more observations for each treatment, and the standard error was less than $20 \%$ of the mean (redrawn from Stein et. al., 1990).

3-E7, a nonspecific endogenous opioid antibody, and a specific antibody to $\beta$ endorphin inhibited the CWS effect but antisera to dynorphin and Met-enkephalin had no effect on the CWS effect (Figure 5). 


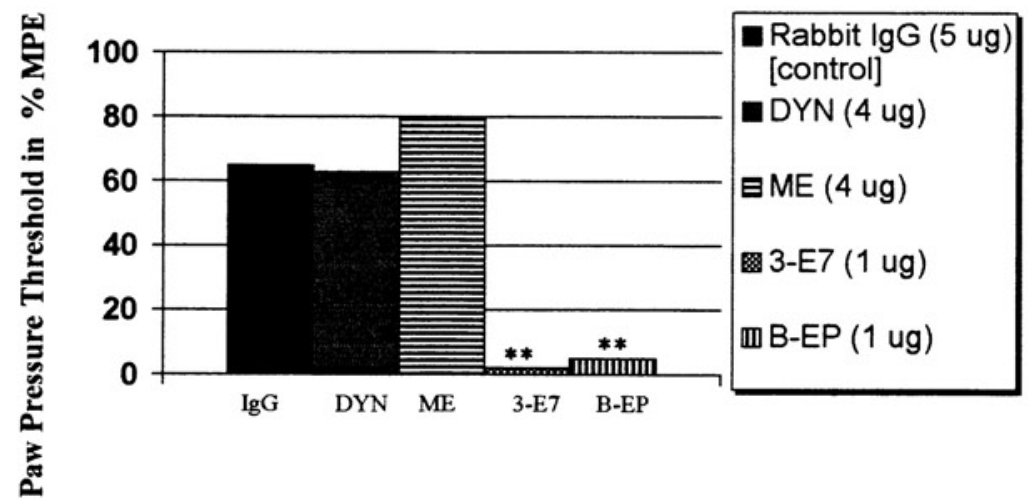

Figure 5: The effects of antibodies against B-endorphin (B-EP), all opiod peptides (3-E7), met-enkaphalin (ME) and dynorphin A (1-17) (DYN) on the elevation of PPT following 1 minute CWS. All antibodies were given 1.5 minutes prior to $\mathrm{CWS}$. ‘ , indicates significant differences between PPT elevations following CWS compared to PPT reduction induced by antisera. There were five or more observations for each treatment and the standard error for each treatment was less than $15 \%$ of the mean (redrawn from Stein et. al., 1990).

I.pl. injection of $\beta$-endorphin (1-31) produced an antinociceptive effect in the inoculated paw which was reversible by i.pl. administration of naloxone and delta and mu selective antagonists (Figure 6). This study suggests that endogenous $\beta$-endorphin, activating local mu and delta receptors, can induce an antinociceptive effect. 


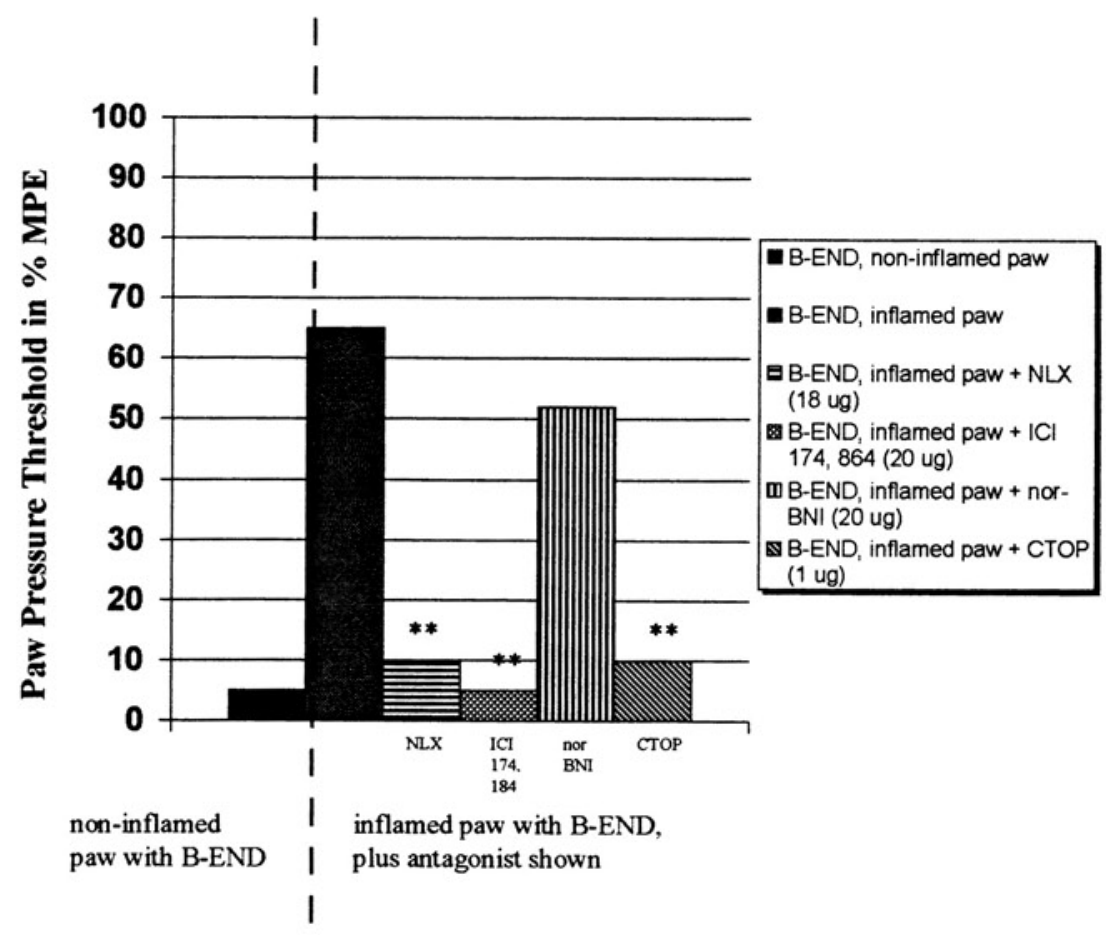

Figure 6: Effects of naloxone (NLX), ICI 174 184, nor-BNI, or CTOP on PPT elevations produced by

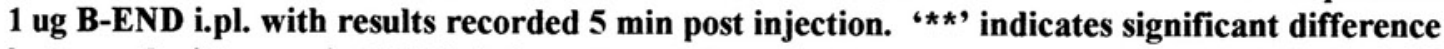
between the increase in PPT in inflamed paws in response to B-END and the reduction of PPT in the presence of antagonists. There were five or more observations for each treatment and the standard error for each treatment was less than $15 \%$ of the mean (redrawn from Stein et. al., 1990).

In a subsequent study, Parsons and Herz (Parsons and Herz, 1990) utilized enkephalinase inhibitors to investigate the possible role of enkephalins in stress induced antinociception. Using Freund's complete adjuvant to induce hind paw inflammation, test animals were subjected to a 1 minute CWS. Paw pressure thresholds were more elevated in the inflamed paw when compared to the non-inflamed paw and both thresholds returned to control levels within 15 minutes. Animals that had previously been injected in both paws with a combination of enkephalinase inhibitors, thiorphan $(0.2 \mathrm{mg}$ i.pl $)$ and bestatin (0.2 mg i.pl.), were then tested. The antinociception was significantly enhanced and prolonged in the inflamed hindpaw of the animals that had received the enkephalinase 
inhibitor cocktail. Furthermore, this pronounced antinociceptive effect was dosedependently antagonized by naloxone $(0.125-2.0 \mathrm{mg} / \mathrm{kg} \mathrm{s.c.})$ and by injections of naltrexone (10-20 mg/kg s.c.).

\section{Possible Sources of Endogenous Opioids Responsible for Peripheral Antinociception}

These studies, taken together, indicate a possible antinociceptive role for endogenous enkephalins and $\beta$-endorphins at local delta and mu opioid receptors; this antinociception is greatly enhanced in the presence of inflammation. Because systemically administered $\beta$ endorphin was unable to elicit an antinociceptive response, the source of the endogenous opioid ligands did not seem to be the hypothalamic-pituitary-adrenal axis. Studies trying to determine the source of endogenous opioids suggest that immunocytes congregating at the sight of inflammation are the source. Stein et al. (Stein et al., 1990) examined tissue from inflamed and the contralateral non-inflamed paws using immunocytochemistry and radioimmunoassay for dynorphin, Met-enkephalin, and $\beta$-endorphin. Inflammation was induced using Freund's complete adjuvant and tissue samples were removed 4 days postinoculation. Radioimmunoassay revealed a substantial increase in Met-enkephalin and $\beta$ endorphin immunoreactivity in the inflamed tissue compared to the non-inflamed tissue and no detectable levels of dynorphin in either tissue. Immunocytochemical studies revealed positive labeling for 3-E7 and a polyclonal antibody for Met-enkephalin. Some cells revealed a very faint signaling for dynorphin. The morphological appearance of opioid containing cells indicated they were lymphocytes, mast cells, macrophages and 
plasma cells. This study further investigated the presence of opioid receptors using the modified immunogold silver staining technique with sodium thiosulfate pretreatment and with Lugol's iodine. Using anti-id-14 (a mouse monoclonal antibody against mu and delta opioid receptors) tissue sections revealed intense staining of immunoreactive opioid receptors on small-diameter cutaneous nerves of both inflamed and non-inflamed tissue. Furthermore, i.pl. injection of anti-id-14, but not i.v. injection, abolished the CWS induced antinociception of the paw pressure test in the inflamed but not the non-inflamed paw. Control IgM was unable to antagonize the antinociceptive effect following CWS. In addition, antibodies to $\beta$-endorphin, Met-enkephalin, and dynorphin were injected i.pl. prior to CWS. Antibodies to $\beta$-endorphin dose dependently inhibited the antinociception following CWS but antibodies to dynorphin and Met-enkephalin had no effect indicating the importance of $\beta$-endorphin in local antinociception.

In order to confirm the role of immune cells in this response, the immunosuppressant cyclosporin A was injected i.p. daily for 3 days prior to CWS. Cyclosporin A inhibits the transcription of early genes promoting the activation of immunocytes and therefore leaves immune cells impaired. This pretreatment, but not that of vehicle, resulted in a dose-dependent inhibition of CWS-induced antinociception in the inflamed paw. To summarize, this study indicates significant amounts of $\beta$-endorphin and Met-enkephalin in the immune cells of inflamed tissue. Immunocytochemical studies also revealed the presence of mu and delta opioid receptors on peripheral sensory nerves. Release of $\beta$-endorphin from immune cells seems to activate these receptors and produce 
an antinociceptive effect following CWS. The role of Met-enkephalin remains unclear and warrants further investigation.

In fact, earlier studies had identified opioid peptides in various immunocytes. Blalock and Smith (1980) demonstrated the presence of POMC-derived peptides in immunocytes as early as 1980 . Other studies demonstrated the presence of preproenkephalin mRNA in mast cells, macrophages and T-cells (Martin et al., 1987). Furthermore, it had been shown that peripheral blood mononuclear cells could release opioid peptides in vitro (Kavelaars et al., 1989) and that corticotropin releasing factor (CRF) could induce the release of endorphins and ACTH from leukocytes (Smith et al., 1986). Przewlocki et al. (1992) sought to determine if these opioid peptides were synthesized at the site of inflammation by trying to identify the presence of both opioid precursor mRNA and opioid peptides at the site of inflammation. In addition, the authors sought to further clarify the types of immunocytes containing the opioid peptides and their proximity to primary sensory neurons by using double staining techniques. Freund's complete adjuvant injection into the hindpaw was used to induce inflammation. Tissue samples were removed for in situ hybridization with probes for prodynorphin, proenkephalin and POMC mRNAs at one and four days post inoculation. Four days post inoculation, tissue samples were also taken for immunocytochemical detection of opioid peptides using polyclonal rabbit antibodies raised against Met-enkephalin, $\beta$-endorphin 131 and dynorphin 1-17. Separate tissue sections were stained with antibodies for specific immune cell antigens to identify T-lymphocytes, B-lymphocytes, macrophages and monocytes. Double staining was utilized to identify the proximity of $\beta$-endorphin 
containing cells to primary sensory neurons by using a polyclonal rabbit anti-calcitonin gene related peptide (CGRP-a marker for sensory neurons in the periphery) antisera. The in situ hybridization studies revealed strong signaling for proenkephalin mRNA and POMC 4 days post inoculation but not at 1 day post inoculation. Prodynorphin mRNA levels were undetectable in all groups, and no signaling for any of the opioid peptide mRNA's was seen in non-inflamed tissue. Immunoreactive Met-enkephalin and $\beta$ endorphin was detected in inflamed tissue in the same areas as elevated levels of their mRNAs suggesting that these opioid peptides are being synthesized at the site of inflammation. T-lymphocytes, B-lymphocytes, macrophages and monocytes taken from the inflamed tissue all stained for $\beta$-endorphin. Double staining revealed cells containing immunoreactive $\beta$-endorphin in close proximity to tissue staining for CGRP which is contained in nerve fibers. Therefore, it is possible for opioid peptides released from these immunocytes to interact with opioid peptides on peripheral nerve endings to produce antinociception. To substantiate this possibility, the authors used whole body irradiation, a method of immunosuppression, of the animals that had received unilateral i.pl. injections of Freund's complete adjuvant. These animals were then subjected to CWS, as in previous studies, in order to test for stress induced antinociception. However, the animals that had been immunosuppressed showed no increased paw pressure threshold following CWS. This latter study further suggests that opioid peptides released from various immunocytes interact with opioid receptors on sensory nerve terminals to produce antinociception in inflamed tissue. 
To further assess the physiological role of $\beta$-endorphin as an endogenous antinociceptive mediator, Rubinstein et al. (1996) used homologous recombination of murine embryonic stem cells to produce mice that could not synthesize $\beta$-endorphin. The proopiomelanocortin gene was targeted; a premature translational stop codon was inserted at the tyrosine codon at position 179. Behavioral and developmental deficiencies were not apparent in the resulting homozygous transgenic mice. Their hypothalamic-pituitaryadrenal axis functioned normally and morphine induced analgesia was present indicating functioning mu-opioid receptors. Following i.p. injections of acetic acid, the abdominal constriction test was used to assess endogenous analgesia induced by the CWS in $\beta$ endorphin deficient and wild-type mice. Following 45 seconds of CWS, wild-type mice exhibited significant antinociception whereas the mutant mice did not. Neither naloxone nor saline, in nonstressed animals, had any antinociceptive effects. However, naloxone reversed the antinociceptive effects in stressed, wild-type mice. This genetic approach further substantiates the evidence that endogenous $\beta$-endorphin plays a role in stress induced analgesia.

\section{Alterations of Opioid Receptors in Sensory Neurons in Response to Inflammation}

The above studies all support the notion that in the presence of inflammation, endogenous opioids, particularly $\beta$-endorphin, have an inhibitory effect on nociception. Pharmacological studies have indicated that these ligands exert their effect at opioid receptors; other types of studies support this hypothesis as well as the hypothesis that 
these opioid receptors are present in the peripheral terminals of primary afferent neurons. As early as 1976, LaMotte et al. employed binding studies to indicate the presence of opioid receptors on dorsal root ganglia. Using autoradiographic binding studies, Fields et al. (1980) identified mu and delta opioid receptors at the central terminals of primary afferent neurons. Their studies further supported previous evidence that opioid receptors are found on the laminae of the dorsal horn where small diameter primary afferents terminate (Hokfelt et al., 1977). Of interest when studying any neuronal receptor protein is if, and how, it is transported to the terminals. Axonal transport can be demonstrated by ligating the peripheral nerve followed by an analysis, often by autoradiographic binding of ligands, of accumulated receptors proximal and distal to the ligature at different time intervals. In 1980, Young et al. reported the axonal transport of opioid receptors in the vagus nerve. A later study conducted by Pierre Laduron (1984) demonstrated the anterograde and retrograde transport of opioid receptors in capsaicin-sensitive neurons suggesting their presence on small "C" fibers in the sciatic nerve of rats. These studies not only confirm the evidence for the presence of opioid receptors in primary afferent neurons but also indicate that they are dynamic receptors fulfilling some role in these neurons.

Because peripheral inflammation has been shown to enhance the antinociceptive effects of opioids and to increase the local quantity of $\beta$-endorphin and Met-enkephalin, Hassan et al. (1993) were interested in determining if inflammation had an effect on the axonal transport of opioid receptors in sciatic nerve. Unilateral intraplantar injections of Freund's complete adjuvant were used to induce inflammation in rats and control animals were given unilateral intraplantar injections of saline. 48 hours following these injections 
the sciatic nerve was surgically exposed and ligated. After 24 or 48 hours post-ligature, the sciatic nerve was surgically re-exposed and a segment of the nerve removed. In addition, subcutaneous tissue was removed from the hindpaws. Binding of $\left[{ }^{125} \mathrm{I}\right]-\beta-$ Endorphin was used to visualize and quantify opioid receptor binding. In unligated sections from sciatic nerve in both inflamed and noninflamed tissue, very little binding was visualized. However, in proximal and distal segments of ligated sciatic nerve from both inflamed and noninflamed paws $\left[{ }^{125} \mathrm{I}\right] \beta$-endorphin binding was present. Opioid receptor binding increased in a time dependent fashion and binding of $\left[{ }^{125} \mathrm{I}\right] \beta$-endorphin was always much greater in sections from the inflamed paw when compared to that of the noninflamed paw. Binding of $\left[{ }^{125} \mathrm{I}\right] \beta$-endorphin was analyzed in subcutaneous tissue from inflamed and noninflamed tissue. As expected, inflamed paw tissue contained intense labeling and the number of binding sites increased as inflammation progressed. The noninflamed paw tissue contained very little labeling. Paw tissue was then analyzed from animals with sciatic nerve ligation. At 24 hours after ligation there was no difference in the quantity of binding sites in subcutaneous tissue when compared to non-ligated tissue. 48 hours after ligation there was a significant drop in the number of binding sites when compared to nonligated tissue indicating that the transport of opioid receptors had been interrupted in the ligated nerve. This study indicates that inflammation induces a change in the quantity of opioid receptors in the peripheral terminals of primary afferent neurons innervating the inflamed region. The time course of accumulation of opioid receptors on either side of the ligature suggests that the fast component of axonal transport is responsible for the receptors movement to the periphery (Hassan et al., 1993). 


\section{Mechanisms of Opioid Antinociception}

The exact mechanism by which the activation of peripheral opioid receptors results in antinociception is unclear. It has been found that opioids inhibit the release of substance P, a proinflammatory agent, in the spinal cord (Yaksh et al., 1980). Similarly, release of proinflammatory, excitatory substances such as substance $\mathrm{P}$ from peripheral nerve terminals is inhibited in response to opioids. It is believed that the decrease in such agents helps to attenuate nociceptive transduction (Yaksh et al., 1988). It is also believed that opioids decrease the excitability of sensory neurons making it more difficult to initiate nociceptive transduction and that opioids reduce the duration of action potentials. Heat hyperalgesia induced by ultraviolet irradiation causes spontaneous firing of polymodal nociceptors which is inhibited by the administration of opioids (Andreev et al., 1994). This inhibition of spontaneous discharge suggests a decrease in the excitability of the sensory neurons. As discussed earlier, there is a decrease in duration of action potentials from the knee joints of cats upon administration of opiates (Russell et al., 1987). These actions of opioids on neurons might be explained by what is known about the action of

opioids on cells. The cell bodies of sensory neurons experience an increase in potassium currents (Werz and MacDonald, 1983) and a decrease in calcium currents when opioid receptors are activated (Schroeder et al., 1991). Such actions throughout the neuron might explain the opioid induced reduction in excitability, reduction in action potential duration, and inhibition of neurotransmitter release (Stein, 1995). 


\section{Does Inflammation Promote Opioid Receptor Activation?}

Opioid receptors are found in peripheral sensory neurons in both normal and inflamed tissues (Fields et al., 1980; Hassan et al., 1993)). However, a local antinociceptive effect induced by an opiate drug is much more readily observed when the drug is administered into inflamed tissue (Stein, 1993). Inflammation must somehow produce conditions that allow for the activation of opioid receptors. Antonijevic et al. (Antonijevic et al., 1995) hypothesize that an inflammation induced disruption of the perineurial membrane allows for the early stages of opioid antinociception. The perineurial membrane surrounds the neurons and acts as a diffusion barrier to large molecules as well as hydrophilic and lipophilic substances. Studies have shown that inflammation disrupts the perineurial barrier in neurons (Olsson, 1990). Antonijevic's study examined the progression of Freund's complete adjuvant induced inflammation along with the corresponding initiation of opioid induced antinociception to determine if perineurial disruption might contribute to opioid agonists' antinociceptive effects. They also sought to determine if mannitol induced or hypertonic saline induced disruption of the perineurial barrier in normal tissue allowed for the analgesic actions of opioids. Mannitol and hypertonic saline are hyperosmolar solutions which disrupt the osmotic equilibrium of the perineurial barrier subsequently "loosening" it. When used, these substances are injected with the agonist, or alone, into the intraplantar region. The temporal progression of signs of inflammation, hyperalgesia, swelling and temperature, were assessed at 1,6 , 
12, 24, and 96 hours after hindpaw inoculation with Freund's complete adjuvant.

Concomitantly, the effects of various selective opioid agonists were evaluated using the paw pressure test. Temperature and volume of inflamed paws increased by 1 hour and plateaued at 12 hours whereas there was no change in noninflamed paws. Within the first 2 hours of inoculation, the paw pressure threshold began to decrease and reached a minimum at 12 hours. There was no change in the paw pressure threshold in noninoculated animals. The earliest elevation of the paw pressure threshold in inoculated hindpaw occurred 6 hours after DAMGO and U-50,488H administration and 12 hours after DPDPE administration. Again, there was no change in paw pressure threshold in noninflamed paws.

Disruption of the perineurial layer was assessed using horseradish peroxidase histochemistry in both inflamed and noninflamed tissue. Barrier disruption is indicated by the ability of horseradish peroxidase to permeate into the inner endoneurial layer of the perineurial membrane. 12 hours after Freund's complete adjuvant injection, horseradish peroxidase was injected subcutaneously. 1 hour later horseradish peroxidase had permeated through the perineurial barrier to the endoneurium. In noninflamed tissue there was no permeation through the barrier by horseradish peroxidase. However, when normal tissue was injected with mannitol or hypertonic saline, horseradish peroxidase was able to permeate the perineurial barrier. In addition, antinociceptive effects of opioids were mimicked in noninflamed paws when treated simultaneously with hyperosmolar mannitol. All three opioid agonists were able to elevate paw pressure threshold in this scenario in a naloxone reversible manner. Mannitol injections alone did not elicit the same 
antinociceptive effects. These results indicate that noninflamed tissue can respond to the antinociceptive actions of opioids through opioid receptors when the perineurial barrier is disrupted as it is when inflammation is present.

To further substantiate these results, fentanyl was injected into one hindpaw of a normal rat (no inflammation was present) and saline was injected into the contralateral paw. Fentanyl is a lipophilic opioid and can therefore pass more readily through the fatty perineurial barrier than a more polar compound. Fentanyl produced dose dependent elevations of paw pressure threshold but there was no change in the paw pressure threshold in the saline injected paws. Mannitol injections significantly enhanced these effects while the effectiveness of fentanyl in the saline treated paw remained unchanged. In rats that had been treated with Freund's complete adjuvant a much lower dose range of fentanyl was required to produce antinociceptive effects whereas this same dose range was ineffective in noninflamed tissue (Figure 7). 


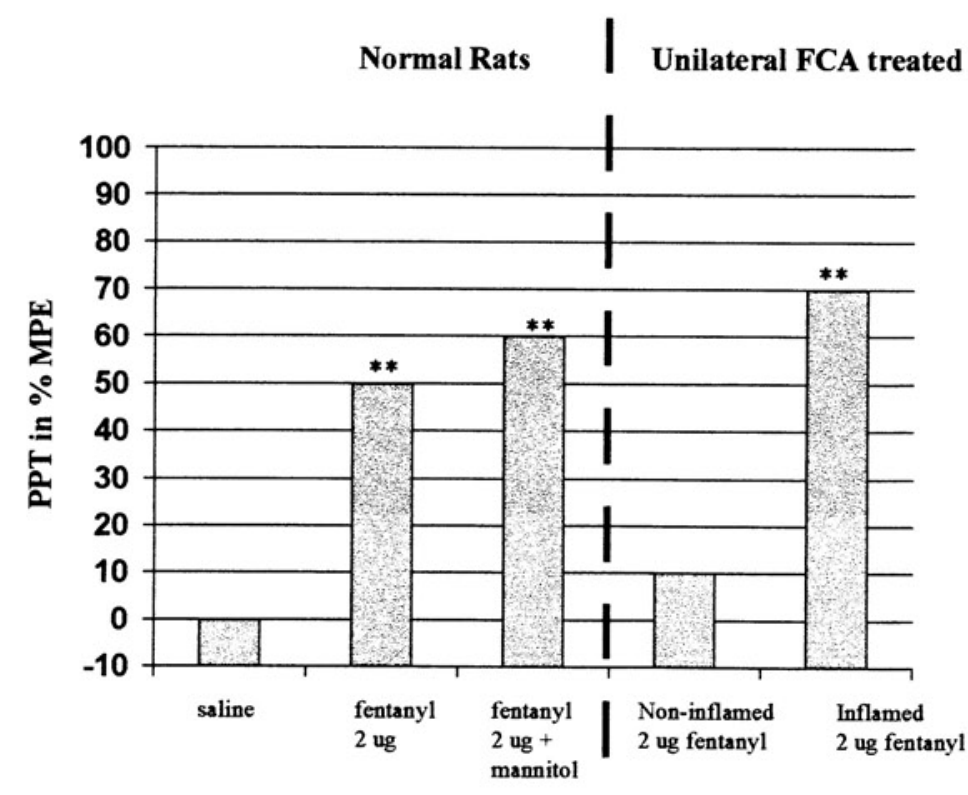

Figure 7: Effects of i.pl. injected fentanyl on PPT in normal rats with and without concomitant injection of mannitol. Effects of fentanyl on PPT in inflamed and non-inflamed; unilateral paw inflammation induced by Freund's complete adjuvant. ' $* \star$ ' indicates a significant difference between control and test animals. There were six or more observations for each treatment, and the standard error for each treatment was less than $10 \%$ of the mean (redrawn from Antonijevic et. al., 1995).

The results of this study suggest that preexisting opioid receptors on sensory neurons are responsible for early onset opioid antinociception in the presence of inflammation. This appears to be due to the disruption of the perineurial barrier which occurs during inflammation and which permits opioids to reach the receptors more readily (Antonijevic et al., 1995).

Stein points out other factors resulting from inflammation, including an increase in the number of sensory neuron terminals in response to inflammation, that may enhance the antinociceptive effects of opioids in the periphery (Stein, 1995). Such "sprouting" 
increases the number of opioid receptors in the vicinity of the inflamed tissue which may allow for a more enhanced opioid response. Stein also suggests that the local environment created by inflammation may activate previously inactive opioid receptors. For instance, inflammation lowers the $\mathrm{pH}$ in the surrounding tissue. A study by Selley et al. (Selley et al., 1993) indicates the increased efficacy of opioid agonists when the $\mathrm{pH}$ is lowered. The lower $\mathrm{pH}$ apparently enhances the interaction of guanine-nucleotide binding proteins with opioid receptors in neuronal membranes. Another environmental change created by inflammation is the increase in neuronal concentrations of cAMP (Ingram and Williams, 1994). According to Stein, the ability of opioids to decrease primary afferent excitability by reducing cation currents as a result of inhibition of adenylate cyclase is enhanced with increased concentrations of cAMP (Stein, 1995). All of the above points may help explain why the presence of inflammation is required for the peripheral antinociceptive actions of opioids to be readily observable.

\section{Factors Affecting the Release of Opioid Peptides from Immune Cells}

Previously discussed studies have presented evidence that inflammation induces the production and release of opioid peptides from immune cells in the vicinity of inflamed tissue (Parsons and Herz, 1990; Stein et al., 1990). It is believed that these opioid peptides activate opioid receptors on the terminals of peripheral sensory neurons, creating an antinociceptive effect. There are many unanswered questions regarding the mediators and mechanisms of the peripheral antinociceptive actions of opioids but it is clear that 
there is a very close interaction with the immune system. One area of investigation has centered on the factor or factors responsible for the release of opioid peptides from immune cells in the periphery. Two studies have been key to answering this question and both have investigated the role that certain cytokines play in this interaction. Cytokines are proteins of low molecular weight that function as communication signals within the immune system and as systemic mediators in response to injury and infection. It was initially believed that cytokines were produced exclusively by immune cells. It is now known that many different types of cells can produce cytokines (Peterson et al., 1998). Studies have shown that peptide hormones, including opioid peptides, can be released from pituitary cells in response to cytokines (Bernton et al., 1987; Fukata et al., 1989; and Fagarasan et al., 1989). In addition, intracerebroventricular injections of interleukin-1 $\beta$ in mice (Nakamura et al., 1988) and in another study, tumor necrosis factor- $\alpha$ (TNF- $\alpha$ ) or interleukin-1 $\beta$ in rats (Sacerdote et al., 1992) have been shown to have an antinociceptive effect. Based on the above data, Andrzej Czlonkowski and colleagues (1993) examined the effects of locally injected cytokines, interleukin- 6 (IL-6) and TNF- $\alpha$, on nociceptive thresholds in rats with unilateral paw inflammation. Freund's complete adjuvant was used to induce unilateral paw inflammation and baseline paw pressure thresholds were determined in both inflamed and noninflamed paws. Animals were then divided into three treatment groups: 1) TNF- $\alpha, 2$ ) IL-6, and 3) saline. These three groups were then subdivided into 2 randomized groups : a) i.pl. injection (a volume of $0.1 \mathrm{ml}$ injected under anesthesia), and b) i.v. injection (a volume of $0.2 \mathrm{ml}$ injected under brief anesthesia). Finally, the intraplantar injection groups were divided into specific dosage groups: [1] low 
(25 ng TNF- $\alpha$; 1 ng IL-6), [2] medium (50 ng TNF- $\alpha ; 10 \mathrm{ng}$ Il-6), and [3] high (100 ng TNF- $\alpha$; 50 ng IL-6). To summarize, there were eight experimental groups (3 i.pl. TNF- $\alpha$, 1 i.v. TNF- $\alpha ; 3$ i.pl. IL-6, 1 i.v. IL-6) and one group which received i.pl. saline. The measurements of paw pressure thresholds were performed at 5, 10 and 20 minutes postinjection on both hindpaws (inflamed and noninflamed). In addition, another group of animals was injected with TNF- $\alpha$ that had been heat inactivated for 15,30 and 45 minutes. Subsequently, paw pressure thresholds were measured in these animals.

The results of this experiment indicate that both TNF- $\alpha$ and IL- 6 given locally increase paw pressure thresholds in the inflamed paw but not in the noninflamed paw. I.V. injection of either one of these substances had no effect on nociceptive thresholds indicating a peripheral site of action (Figure 8 and Figure 9). Heat inactivation of TNF- $\alpha$ produced a time dependent reduction in its antinociceptive effect which was completely abolished after 45 minutes of heat inactivation. This results suggest that the effect is due to a polypeptide. 


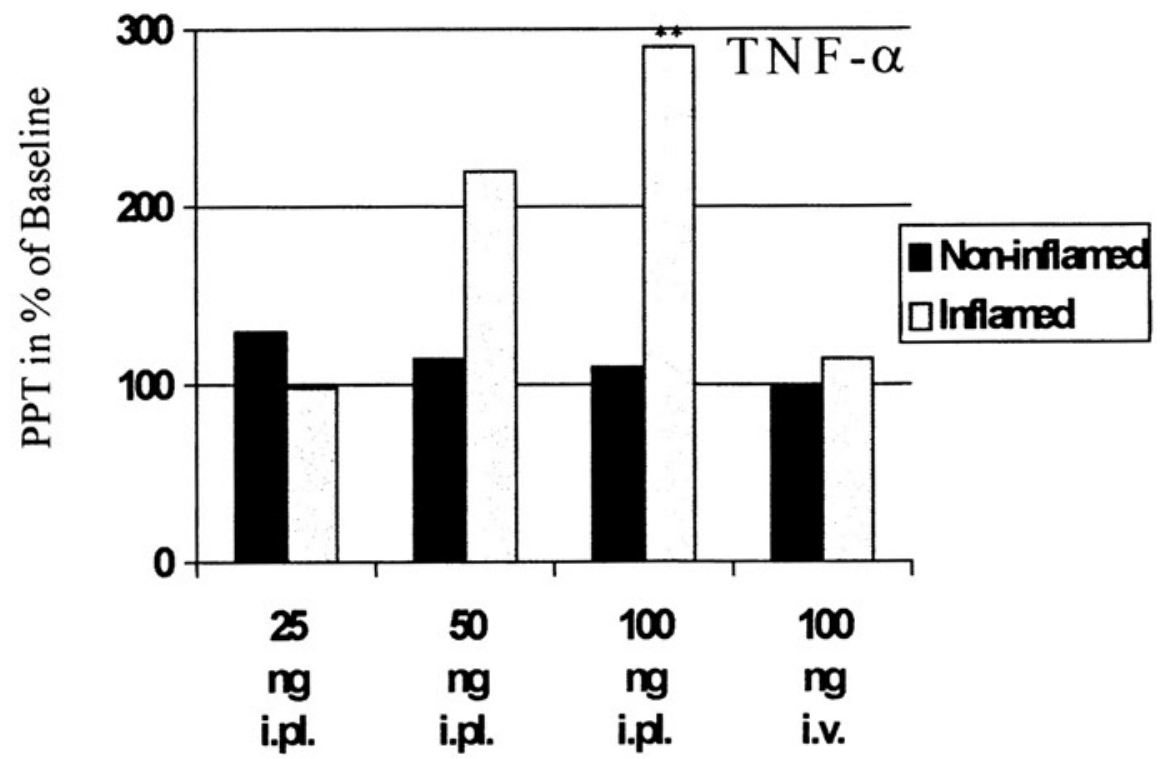

Figure 8: Effect of various doses of i.pl. of TNF- $\alpha$ on Paw Pressure Threshold 5 minutes after injection in inflamed and non-inflamed paws. ' $\star *$ ' indicates significant differences between inflamed and non-inflamed paws. There were six or more observations for each treatment, and the standard error for each treatment was less than $20 \%$ of the mean (redrawn from Czlonkowski et. al., 1993). 


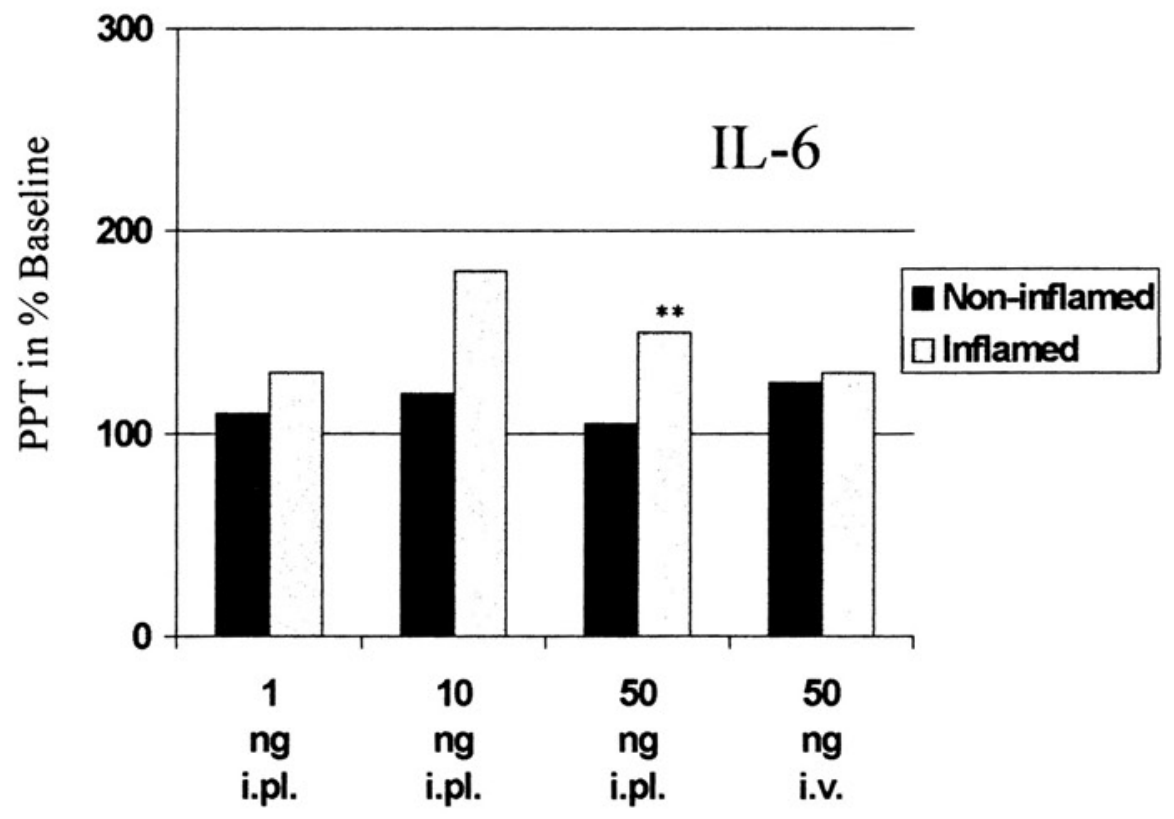

Figure 9: Effect of various doses of i.pl. of IL-6 on Paw Pressure Threshold 5 minutes after injection in inflamed and non-inflamed paws. " $*$ ' ' indicates significant differences between inflamed and non-inflamed paws. There were six or more observations for each treatment, and the standard error for each treatment was less than $15 \%$ of the mean (redrawn from Czlonkowski et. al., 1993).

A second experiment investigated the effects of various opioid antagonists and antibodies on paw pressure thresholds in cytokine treated animals. The following selective opioid antagonists were used: 1) mu - CTOP (D-Phe-Cys-Tyr-D-Trp-Art-ThrPen-Thr-NH2), 1 ug; 2) delta - ICI 174,864 (N,N-diallyl-Tyr-Aib-Aib-Phe-Leu), 40 ug; 3) kappa - Norbinaltorphimine, $200 \mathrm{ug}$; and 4)the universal opioid antagonist, naloxone (10 $40 \mathrm{ug}$ ). In addition, the monoclonal antibody 3-E7, an antibody against all opioids, and a specific polyclonal antibody to $\beta$-endorphin were used in the cytokine treated animals to test for changes in paw pressure thresholds. These substances were injected concomitantly with TNF- $\alpha$ (100 ng, left hindpaw) and Il-6 (50 ng, right hindpaw) and paw 
pressure thresholds were measured at 5 minutes. Control rats were injected with i.pl. saline.

In a dose dependent manner, CTOP and naloxone antagonized the effects of TNF$\alpha$ indicated by the decrease in the paw pressure threshold. The paw pressure threshold for the saline injected animals remained unchanged. The antinociceptive effect of TNF- $\alpha$ was also antagonized by 40 ug ICI 174,864 and attenuated by 3 -E7 but not by 200 ug norbinaltorphimine or by the polyclonal antibody against $\beta$-endorphin. The antinociceptive effect of IL- 6 was antagonized by CTOP, nor-binaltorphimine and naloxone but not by ICI 174,864. Both the universal opioid peptide antibody 3-E7 and the specific $\beta$-endorphin antibody were able to antagonize the antinociceptive effects of interleukin-6.

The third experiment undertaken by Czlonkowski evaluated the effects of cyclosporin A on the immune system and its effects on nociception. Cyclosporin A inhibits the transcription of early genes promoting the activation of immunocytes and therefore leaves immune cells impaired. The test rats were divided into three cyclosporin A treatment groups : 1) $2.25 \mathrm{mg}, 2$ ) $4.5 \mathrm{mg}$, and 3) $9.0 \mathrm{mg}$, and a vehicle injected control group. These rats were injected intraperitoneally on days 2, 3, and 4 after Freund's complete adjuvant inoculation. Test animals were then injected with TNF- $\alpha$ (100 ng i.pl.) and paw pressure thresholds were measured 5,10 , and 20 minutes after TNF- $\alpha$ administration. The treatment with cyclosporin $\mathrm{A}$ also resulted in a dose dependent inhibition of the antinociceptive effects of TNF- $\alpha$. The data collected from all of the above experiments suggests that the cytokines TNF- $\alpha$ and IL- 6 are involved in the peripheral antinociceptive actions of opioid peptides. Specifically, because TNF- $\alpha$ and IL- 
6 have an antinociceptive effect which is abolished by opioid antagonist, the authors believe that the cytokines help to release $\beta$-endorphin and enkephalin from the immune cells infiltrating the area of inflammation.

Michael Schafer et al. (1994) performed a similar experiment based on the findings that opioid peptides were produced in immune cells in the presence of inflammation and that peptides can be released from immune cells in response to certain cytokines. This information suggests a functional connection between the immune system and the nervous system. The goal of this experiment was to determine if corticotropin-releasing factor and interleukin $1 \beta$ inhibit pain by releasing opioid peptides from immune cells within inflamed tissue in vivo and to test for $\beta$-endorphin release from immune cells in vitro. They base their hypothesis on the findings of Heijnen et al. (1991) who found that these two substances stimulate the release of $\beta$-endorphins in long-term cultured immune cells. Schafer used unilateral hindpaw injections of Freund's complete adjuvant to induce unilateral paw inflammation. The first experiment was designed to test time course and dose-response of the antinociceptive effects of i.pl. administered IL-1 $\beta(0.1-2.0 \mathrm{ng})$ or CRF (0.1 - $1.5 \mathrm{ng})$ and i.v. administered IL-1 $\beta$ or CRF when compared to control groups (saline injected). The administration of these substances was done 4-5 days postinoculation and was preceded by the determination of baseline paw pressure thresholds. They also tested to see if these effects were antagonized by recombinant IL-1 $\beta$ receptor antagonist (IL-1ra), CRF antagonist ( $\alpha$-helical CRF), CTOP, norbinaltorphimine, ICI 174,864 , naloxone, rabbit anti $\beta$-endorphin, rabbit anti-[Met]enkephalin, and rabbit antidynorphin A. Pretreatment with cyclosporin A 48, 24 and 4 hours before testing was 
examined in a separate group of animals treated with IL-1 $\beta$ or CRF. Paw pressure thresholds were then measured 5, 10, and 20 minutes after the injection.

The results of this experiment demonstrated a dose dependent elevation in paw pressure threshold in the inflamed paw but not in the noninflamed paw following i.pl. injections of IL- $1 \beta$ or CRF. The maximum elevations were demonstrated in the highest dose of both Il-1 $\beta$ and CRF. I.V. administration of these substances was ineffective in changing the paw pressure threshold. Antagonism was demonstrated for Il-1 $\beta$ with Il-1ra, anti- $\beta$-endorphin, anti-dynorphin, naloxone, CTOP, ICI 174,864, and norbinaltorphimine but not with anti-[Met]-enkephalin. CRF was antagonized by $\alpha$-helical CRF, anti- $\beta$ endorphin, anti-[Met]enkephalin, naloxone, CTOP, and ICI 174,864 but not by antidynorphin A or norbinaltophimine. Cyclosporin A treated animals exhibited a dose dependent inhibition of the antinociception induced by both Il-1 $\beta$ and CRF.

In the second experiment, immunoreactivity of $\beta$-endorphin was measured in cell suspensions prepared from inflamed lymph nodes. Four - five days after intraplantar inoculation with Freund's complete adjuvant rats were euthanized with $\mathrm{CO}_{2}$ inhalation and popiteal lymph nodes removed, ground and reconstituted in Hank's balanced salt solution. After centrifugation, these cells were resuspended in Hank's balanced salt solution for a final cell concentration of $0.05-0.15 \times 106$ cells per $\mathrm{ml} .0 .3 \mathrm{ml}$ of this solution was incubated with either Hank's balanced salt solution, $\alpha$-helical CRF (25-100 ng) or IL-1ra (25 - $100 \mathrm{ng})$. After 5 minutes either Hank's balanced salt solution, CRF (25-100 ng), or IL-1 $\beta$ (25 - $100 \mathrm{ng})$ was added. After another 5 minutes, the cell suspensions were 
centrifuged and the supernatant stored for radioimmunoassays to detect the release of $\beta$ endorphin.

The results of this experiment produced a dose-dependent release of immunoreactive (ir) $\beta$-endorphin from immune cells treated with IL-1 $\beta$ and CRF. IL-1 (100 ng) release was dose-dependently inhibited by IL-1ra but not by $\alpha$-helical CRF. CRF (100 ng) release was dose-dependently decreased by $\alpha$-helical CRF but not by IL-1ra (Figure 10 and Figure 11).

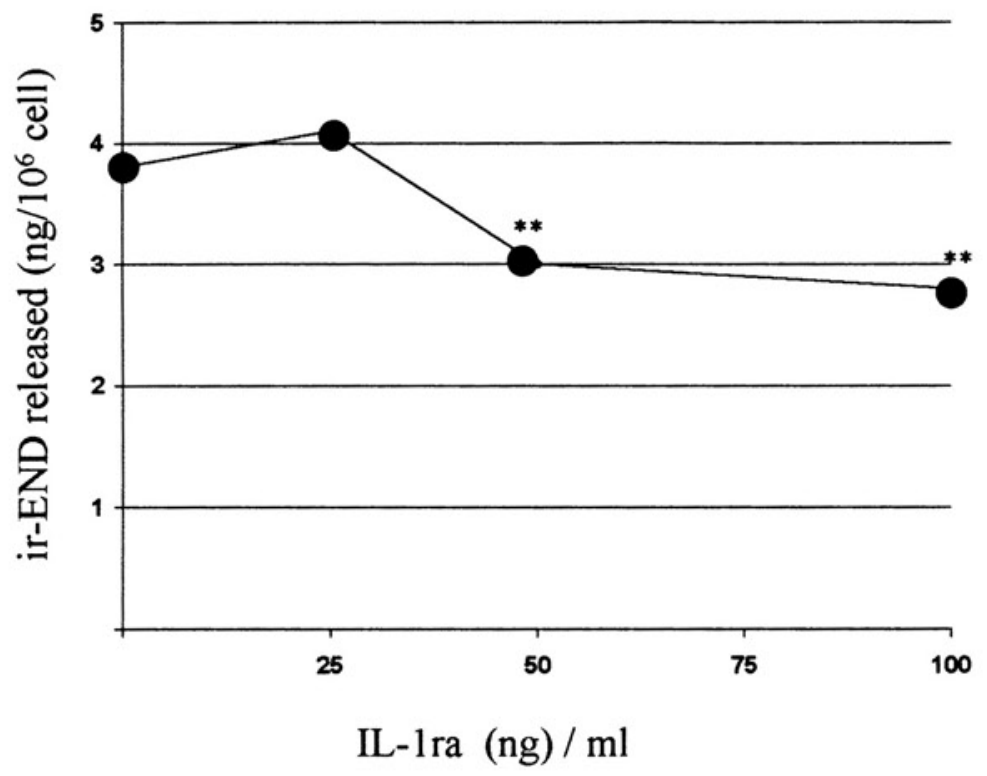

Figure 10: Inhibition of release of ir-END in response to IL-1ra in lymph node cells stimulated with $100 \mathrm{ng}$ IL-1 $\beta$. ' **' indicates a significant difference between cells treated with $100 \mathrm{ng}$ IL-1 $\beta$ in the absence and presence of IL-1ra. There were four or more observations per treatment, and the standard error for each treatment was less than $20 \%$ of the mean (redrawn from Schafer et. al., 1994). 


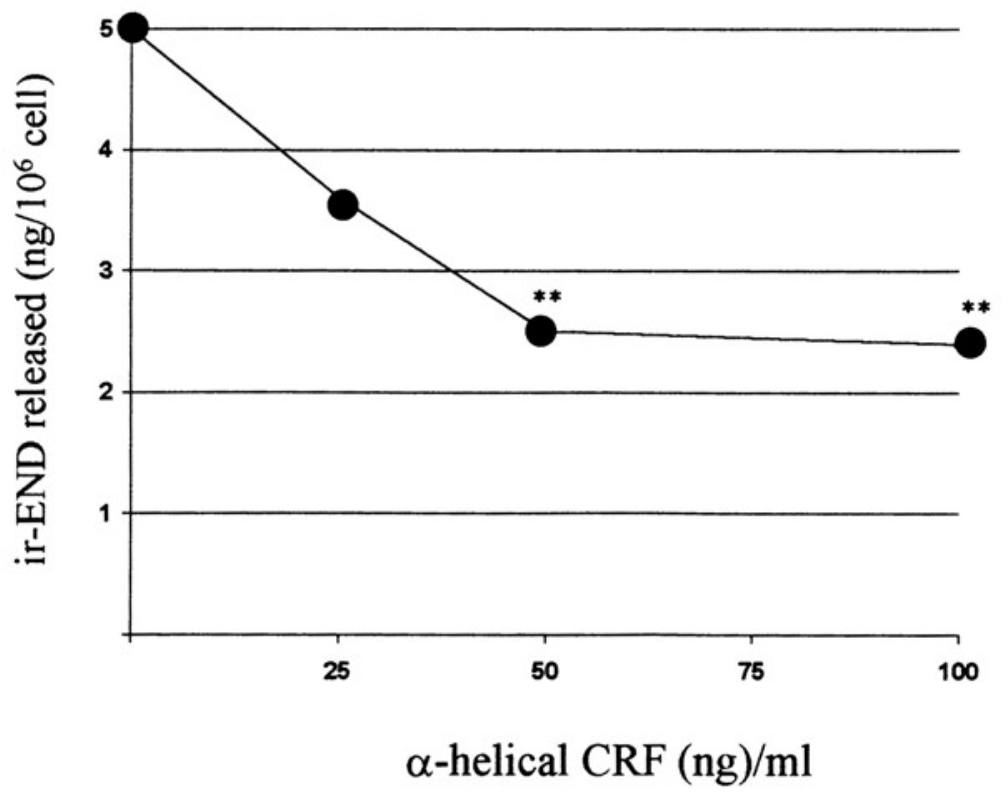

Figure 11: Inhibition of release of ir-END in response to $\alpha$ - helical CRF in lymph node cells stimulated with $100 \mathrm{ng}$ CRF. ' $\star *$ ' indicates a significant difference between cells treated with 100 ng CRF in the absence and presence of IL-1 ra. There were four or more observations per treatment, and the standard error for each treatment was less than $15 \%$ of the mean (redrawn from Schafer et. al., 1994).

The results of the above experiments indicate that both $\mathrm{IL}-1 \beta$ and $\mathrm{CRF}$ can act in an antinociceptive manner in peripheral inflamed tissue. Because the IL-1 $\beta$ and CRF antinociception is dose dependent and antagonized by their respective antagonists, these effects appear to be mediated through the receptors for IL-1 $\beta$ and CRF. The authors further suggest that the location of the receptors mediating this effect is on the immune cells infiltrating the area because of the effects of cyclosporin A. In this experiments, paw swelling was not affected by the pretreatment suggesting that inflammation was present but the antinociceptive effects of IL-1 $\beta$ and CRF were abolished. The authors therefore 
believe that the receptors for $\mathrm{IL}-1 \beta$ and CRF that mediate the antinociceptive effects must be on immune cells which, when treated with cylcosporin $\mathrm{A}$, lose their integrity and therefore their ability to mediate the antinociceptive effects. Finally, the results suggest that activation of the Il-1 $\beta$ and CRF receptors on immunocytes facilitates the release of opioid peptides from these cells. These peptides then activate opioid receptors on the peripheral terminals of sensory neurons to produce antinociception. It is interesting to note that there is a differential release of opioids by these two substances as antidynorphin antibody inhibited the effects of $\mathrm{IL}-1 \beta$ but not $\mathrm{CRF}$, and anti-[Met]-enkephalin antibody inhibited the effects of CRF but not of IL-1 $\beta$. The different effects of the selective antagonists further support these findings. The results indicate that CRF effects are mediated through mu and delta opioid receptors but not through kappa opioid receptors, while all three receptors (mu, delta and kappa) are involved in the effects of IL-1 $\beta$ (Schafer et al., 1994).

\section{Human Studies of Peripheral Opioid Analgesia}

The above mentioned studies utilized laboratory rats. Obviously, analgesia in humans is the ultimate goal of pain research and several studies using surgery patients have been performed by Christoph Stein (1991). His findings, summarized below, justify further investigations into this field. The patients involved in these studies underwent arthroscopic knee surgery. Postoperatively it was found that those patients receiving intraarticular (i.a.) doses of morphine scored lower on pain test than those receiving an 
equivalent dose intravenously. In addition, the doses of morphine administered were lower than those generally given systematically to control pain and the i.a. analgesic effect was abolished by the opioid antagonist naloxone. These findings indicate that peripheral opioid receptors can mediate analgesia (Stein, 1991). In a subsequent study, tissue samples were taken from the injured area and immunohistochemical studies revealed the presence of $\beta$-endorphin and Met-enkephalin. The cells containing these peptides had characteristics consistent with certain immunocytes. Postoperatively, these patients received either intraarticular naloxone or intravenous naloxone at equal doses. Those receiving the i.a. dose scored higher on pain measurement test and requested more supplemental doses of analgesics than those receiving the i.v. dose of naloxone. These results suggest that opioid peptides are present in inflamed tissue and act to reduce pain at the site (Stein et al., 1993).

A more recent study compared arthroscopic knee surgery patients with and without synovial cellular infiltrates. The objective of the study was to determine if there was a difference in pain assessment between the two groups upon receiving morphine injections, either i.a. or i.v., with the notion that those patients with opioid peptidecontaining cellular infiltrates may have developed tolerance to opioids due to the continuous presence of endogenous opioid peptides. As expected, morphine was much more effective in both groups of patients when the morphine was administered i.a. vs. i.v. and those with cellular infiltrates actually scored lower on the pain measurement tests than those without cellular infiltrates. In addition, autoradiographic binding studies revealed no difference in the number of opioid receptors on the sensory nerve terminals between 
samples taken from both groups thus no receptor downregulation occurred. These findings suggest that repeated applications of opioids at peripheral sites may not result in the rapid induction of tolerance, a concern that might have limited the therapeutic applications of this route of administration (Stein et al., 1996).

The studies outlined above give substantial support to the notion that opioids have a peripheral antinociceptive role in the presence of inflammation. Furthermore, some of these studies provide further evidence of a complicated relationship between the immune system and the nervous system. Further research in these areas may lead to the development of a morphine-like substance can be produced that will not pass through the blood-brain barrier but can exert its analgesic effects in the periphery. Clearly more clinical research needs to be conducted, but there are several questions that need to be researched in the laboratory as well:

1. Is there truly an increase in opioid receptors on peripheral sensory nerve terminals in the presence of inflammation? If so, is there an actual increase in the transcription and translation of these receptors or is there an increase in the transport of intracellular receptors from the cell body to the plasma membrane at the nerve terminals. Also, which receptor type(s) are involved and if there is an increase in the production of receptors, what factor(s) is responsible for the increased transcription and/or translation? What factor(s) are responsible for any increased transport? 
2. If an increase in peripheral opioid receptors is a factor in the enhanced opioid analgesia in the periphery, what factor or process is responsible for the return to basal levels of receptors? Can this process be manipulated so that receptors remain in the periphery to prolong the antinociceptive effect?

3. In inflamed tissue, what is the fate of peripheral opioids? Many studies indicate a maximal effect within 10 minutes; what is terminating the opioids' effect? Is it an enzymatic process? an immunological process? or an environmental process such as $\mathrm{pH}$ ? Can the termination process be manipulated so that opioids can remain in the environment for longer periods of time?

4. Are there cytokines other than TNF- $\alpha, \mathrm{IL}-1 \beta$, and IL- 6 or factors other than CRF which affect peripheral opioid analgesia?

5. Are the receptors for cytokines on immune cells static or dynamic? Can they be manipulated to increase the production and release of opioids?

6. Can the injection of cytokines into peripherally inflamed tissue in humans produce analgesia?

7. Does desensitization occur in opioid receptors in the periphery? If so, which subtypes of receptors are involved in peripheral opioid analgesia and can the development of selective peripheral agonists be interchanged in order to produce analgesia but diminish any desensitization?

The answer to some or all of these questions would help in the development of better pain management strategies using opioid compounds. 


\begin{abstract}
ABBREVIATIONS
5-HT, 5-hydroxytryptamine, Serotonin; $\alpha$-MSH, $\alpha$-melanocyte-stimulating hormone; ACTH, adrenocorticotrophic hormone; $\beta$-LPH, $\beta$-lipotropin; bp, base pairs; $\mathrm{Ca}^{++}$, calcium; cAMP, cyclic adenosine monophosphate; CGRP, calcitonin gene related peptide; $\mathrm{CI} 977$, (5R)$(5 \alpha, 7 \alpha, 8 \beta)-N$-methyl- $N$-(7-[-1-pyrrolidinyl]-1-oxaspiro[4,5]dec-8-yl)-4-benzofuranacetamide monohydrochloride; CNS, central nervous system; CRF, corticotropin releasing factor; $\mathrm{CRH}$, corticotropin releasing hormone; CTAP, DPhe-Cys-Tyr-DTrp-Arg-Thr-Pen-Thr- $\mathrm{NH}_{2 ;}$ CTOP, DPhe-Cys-Tyr-DTrp-Lys -Thr-Pen-Thr- $\mathrm{NH}_{2}$; CWS, cold water swim; DADLE, [DAla ${ }^{2}$, Dleu $\left.{ }^{5}\right]$ enkephalin; DAG, diacylglycerol; DAMGO, Tyr-DAla-Gly-[N-MePhe]-NH( $\left(\mathrm{CH}_{2}\right)_{2}-\mathrm{OH}$; DOR-1, delta opioid receptor 1; DPDPE, [DPen ${ }^{2}, \mathrm{DPen}^{5}$ ] enkephalin; DRG, dorsal root ganglia; DSBULET, Tyr-DSer(OtBu)-Gly-Phe-Leu-Thr; DYN B, dynorphin B; DYN, Dynorphin A; $\mathrm{ED}_{50}$, median effective dose; EKC, ethylketocyclazocine; $\gamma$-LPH, $\gamma$-lipotropin; $\gamma$-MSH, $\gamma$ melanocyte-stimulating hormone; G-proteins, guanine nucleotide-binding protein; $\mathrm{G}_{\mathrm{i}}$, inhibitory G-protein; $\mathrm{G}_{\mathrm{s}}$, stimulatory G-protein; GABA, $\gamma$-aminobutyric acid; i.a., intraarticular; $\mathrm{ID}_{50}$, median inhibitory dose; i.p., intraperitoneal; i.pl, intraplantar; i.v., intravenously; ICI 174,864, N,N-diallyl-Tyr-Aib-Aib-Phe-Leu; ICV, intracerebroventricular; IL-1 $\beta$, interleukin-1 $\beta$; IL-1ra, interleukin $1 \beta$ receptor antagonist; $\mathrm{IL}-6$, interleukin-6; $\mathrm{IP}_{3}, 1,4,5$-inositol-trisphosphate; irEND, immunoreactive $\beta$-endorphin; $\mathrm{K}^{+}$, potassium; LC, locus ceruleus; Leu-enkephalin, leucine-enkephalin; Met-enkephalin, methionine-enkephalin; mRNA, messenger RNA; NRGC, nucleus reticularis gigantocellularis; NRM, nucleus raphe magnus; PAG, periaqueductal gray matter; PAN, primary afferent nociceptors; PBQ, Phenyl-p-benzoquinone; PDYN, prodynorphin; $\mathrm{PGE}_{2}$, Prostaglandin $\mathrm{E}_{2} ; \mathrm{PL} 017,\left[\mathrm{~N}-\mathrm{MePhe}^{3}, \mathrm{DPro}^{4}\right]$ morphiceptin; POMC, Proopiomelanocortin; PPT, paw pressure threshold; s.c., subcutaneously; SKF-10,047, Nallylnormetazocine; TIPP, H-Tyr-Tic-Phe-OH; TNF- $\alpha$, tumor necrosis factor- $\alpha$; U6959, $5 \alpha, 7 \alpha, \beta-(-)-N$-methyl- $N$-[7-(1-pyrrolidinyl)-1-oxaspiro-4,5)dec-8-yl]benzene acetamide; U$50,488 \mathrm{H}$, [trans-( \pm )-3,4-dichloro- $N$-methyl-[2-(1-pyrrolidinyl) cyclohexyl]-benzene-acetamide
\end{abstract}




\section{REFERENCES}

1. Allen A C, Gammon C M, Ousley A H, McCarthy K D, Morell P (1992) Bradykinin stimulates arachidonic acid release through the sequential actions of an sn-1 diacylglycerol lipase and a monoacylglycerol lipase. Journal of Neurochemistry $\mathbf{5 8}$, 1130-1139.

2. Andreev N, Urban L, Dray A (1994) Opioids suppress spontaneous activity of polymodal nociceptors in rat paw skin induced by ultraviolet irradiation. Neuroscience 58(4), 793-798.

3. Antonijevic I, Mousa S, Schafer M, Stein C (1995) Perineurial defect and peripheral opioid analgesia in inflammation. Journal of Neuroscience 15(1), 165-172.

4. Basbaum AI, Fields HL (1984) Endogenous pain control systems: brainstem spinal pathways and endorphin circuitry. Annual Review of Neuroscience 7, 309-338.

5. Beckett AH, Casy AF (1954) Synthetic analgesics: stereochemical considerations. $J$ Pharm Pharmacol 6, 986-999.

6. Bentley GA, Newton SH, Starr J (1981) Evidence for an action of morphine and the enkephalins on sensory nerve endings in the mouse peritoneum. Br J Pharmacol 73, $325-332$.

7. Bernton E, Beach JE, Holaday JW, Smallridge RC, Fein HG (1987) Release of multiple hormones by a direct action of interleukin-1 on pituitary cells. Science 238, 519-521.

8. Blalock and Smith (1980) Human leukocyte interferon: structural and biological relatedness to adrenocorticotropic hormone and endorphins. Proc Natl Acad Sci 77, 5972-5974.

9. Bodnar RJ, Williams CL, Lee SJ, Pasternak GW (1988) Role of $\mu$-opiate receptors in supraspinal analgesia: a microinjection study. Brain Research 447, 25-34.

10. Brownstein MJ (1993) A brief history of opiates, opioid peptides, and opioid receptors. Proc Natl Acad Sci 90, 5391-5393.

11. Carroll MN, Lim RKS (1960) Observation of the neuropharmocology of morphine and morphine-like analgesia. Arc. Intern Pharmacodyn 125, 383-403. 
12. Chen Y, Mestek A, Liu J, Hurley JA, Yu L (1993) Molecular cloning and functional expression of a mu-opioid receptor from rat brain. Mol Pharmacol 44, 8-12.

13. Childers SR (1991) Opioid receptor-coupled second messenger systems. Life Sci 48, 1991-2003.

14. Childers SR (1988) Opioid-coupled second messenger systems. In: The Opiate Receptors, Gavril W. Pasternak (ed) The Humana Press, Clifton, pp. 231-263.

15. Collier H, Roy A (1974) Morphine-like drugs inhibit the stimulation by $\mathrm{E}$ prostaglandins of cyclic AMP formation by rat brain homogenates. Nature 248, 24-27.

16. Czlonkowski A, Stein C, and Herz A (1993) Peripheral mechanisms of opioid antinociception in inflammation: involvement of cytokines. Eur J Pharmacol 242, 229235.

17. Evans CJ, Keith DE, Morrison H, Magendzo K, Edwards RH (1992) Cloning of a delta opioid receptor by functional expression. Science 258, 1952-1955.

18. Evans C, Hammonds D, Frederickson R (1988) The Opioid Peptides. In: The Opiate Receptors, Gavril W. Pasternak (ed) The Humana Press, Clifton, pp. 23-71.

19. Fagarasan MO, Eskay R, Axelrod J (1989) Interleukin 1 potentiates the secretion of beta-endorphin induced by secretagogues in a mouse pituitary cell line (AtT-20). Proc Natl Acad Sci 86, 2070.

20. Falus A, Meretey K (1992) Histamine: an early messenger in inflammatory and immune reactions. Immunology Today 13, 154-156.

21. Ferreira SH, Nakamura M (1979) Prostaglandin hyperalgesia II: the peripheral analgesic activity of morphine, enkephalins and opioid antagonists. Prostaglandins 18 , 191-200.

22. Ferreira SH, Molina N, Vettore O (1982) Prostaglandin hyperalgesia, V: a peripheral analgesic receptor for opiates. Prostaglandins 23, 53-60.

23. Ferreira SH, Lorenzetti BB, Rae GA (1984) Is methyl-nalorphinium the prototype of an ideal peripheral analgesic? Eur J Pharmacol 99, 23-9.

24. Fields HL, Emson PC, Leigh BK, Gilbert RF, Iversen LL (1980) Multiple opiate receptor sites on primary afferent fibres. Nature 284, 351-353. 
25. Follenfant RL, Hardy GW, Lowe LA, Schneider C, Smith TW (1988) Antinociceptive effects of the novel opioid peptide BW443C competed with classical opiates; peripheral versus central actions. Br J Pharmacol 93, 85-92.

26. Fukata JT, Usui T, Naitoh Y, Nakai Y, Imura H (1989) Effects of recombinant human interleukin-1 alpha, -1 beta, 2 and 6 on ACTH synthesis and release in the mouse pituitary tumour cell line AtT-20. J Endocrinology 122(1), 33-39.

27. Ghosh A, Ginty D, Baking H, Greenberg M (1994) Calcium regulation of gene expression in neuronal cells. Journal of Neurobiology 25(3), 294-303.

28. Goldstein A, Lowney LI, Pal BK (1971) Steroespecific and non-specific interactions of the morphine congener levorphanol in subcellular fractions of mouse brain. Proc Natl Acad Sci 6, 1742-1747.

29. Gross RA, Hylan CM, Uhler MD, MacDonald RL (1990) Dynorphin A and cAMPdependent protein kinase independently regulate neuronal calcium currents. Proc Natl Acad Sci 87, 7025-7029.

30. Guilbaud G, Bernard JF, Besson JM (1994) Brain Areas involved in nociception. In: Textbook of Pain, Wall P, and Melzack R, (eds) Churchill Livingston, Edinburgh, pp. 113-128.

31. Hassan AHS, Ableitner A, Stein C, Herz A (1993) Inflammation of the rat paw enhances axonal transport of opioid receptors in the sciatic nerve and increases their density in the inflamed tissue. Neuroscience 55, 18-195.

32. Heijnen C, Kavelaars A, Ballieux R (1991) $\beta$-endorphin: cytocine and neuropeptide. Immunol Rev 119, 41-63.

33. Hokfelt T, Ljungdahl A, Terenius L, Elde R, Nilsson G (1977) Proc Natl Acad Sci 74, 3081-3085.

34. Hollt V (1993) Regulation of Opioid Peptide Gene Expression. In: Opioids I, A. Herz (ed) Springer-Verlag, Berlin, pp. 307-377.

35. Ingram SL, Williams JT (1994) Opioid inhibition of $I_{h}$ via adenylyl cyclase. Neuron 13, 179-186.

36. Kavelaars A, Ballieux R, Heijnen C (1989) The role of IL-1 in corticotropin-releasing factor and argiinine-vasopressin-induced secretion of immunoreactive $\beta$-endorphin by human peripheral blood mononuclear cells. J Immunology 142, 2338-2342. 
37. Kieffer, BL (1995) Recent advances in molecular recognition and signal transduction of active peptides: receptors for opioid peptides. Cellular and Molecular Neurobiology 15(6), 615-635.

38. Laduron Pierre (1984) Axonal transport of opiate receptors in capsaicin-sensitive neurones. Brain Research 294, 157-160.

39. LaMotte C, Pert CB, Snyder SH (1976) Opiate receptor binding in primate spinal cord: distribution and changes after dorsal root section. Brain Research 112, 407-12.

40. Le Bars D, Nillanueva L (1988) Electrophysiological evidence for the activation of descending inhibitory controls by nociceptive afferent pathways. In: Pain Modulation, HL fields and JM Besson (ed) Elsevier, New York, pp. 275-300.

41. Levine JD, Taiwo YO (1989) Involvement of the mu-opiate receptor in peripheral analgesia. Neuroscience 32, 571-575.

42. Levine JD, Fields HL, Basbaum AI (1993) Peptides and primary afferent nociceptor. $J$ Neuroscience 13(6), 2273-2286.

43. Lipp J (1991) Possible mechanisms of morphine analgesia. Clinical Neuropharmacology, 14(2) 131-147.

44. Lord JAH, Waterfield AA, Hughes J, Kosterlitz HW (1977) Endogenous opioid peptides: Multiple agonists and receptors. Nature (Lond.) 267, 495-499.

45. Martin J, Prystowsky MB, Angeletti RH (1987) Preproenkephalin mRNA in T-cells, macrophages and mast cells. J Neuroscience 18, 82-87.

46. Martin WR, Eades CG, Fraser HF, Wikler A (1964) Use of hindlimb reflexes of the chronic spinal dog for comparing analgesics. Journal of Pharmacology and Experimental Therapeutics 144, 8-11.

47. Martin WR, Eades CG, Thompson JA, Huppler RE, Gilbert PE (1976) The effects of morphine- and nalorphine-like drugs in the nondependent and morphine-dependent chronic spinal dog. J. Pharmacol Exp Ther 197, 517-532.

48. Nakamura H, Nakanishi K, Kita A, Kadokawa T, (1988) Interleukin-1 induces analgesia in mice by a central action. Eur J Pharmacol 149(1-2), 49-54.

49. North RA, Williams JT, Suprenant A, Christie MJ (1987) $\mu$ and $\delta$ receptors belong to a family of receptors that are coupled to potassium channels. Proc Natl Acad Sci 84, 5487-5491. 
50. Olsson Y (1990) Microenvironment of the peripheral nervous system under normal and pathological conditions. Critical Review in Neurobiology 5, 265-311.

51. Parsons CG, Herz A (1990) Peripheral opioid receptors mediating antinociception in inflammation. Evidence for activation by enkephalin-like opioid peptides after cold water swim stress. J Pharmacol Exp Ther 255, 795-802.

52. Parsons CG, Czlonkowski A, Stein C, Herz A (1990) Peripheral opioid receptors mediating antinociception in inflammation. Activation by endogenous opioids and role of the pituitary-adrenal axis. Pain 41, 81-93.

53. Pert CB, Snyder SH (1973) Opiate receptor: demonstration in nervous tissue. Science 179, 1011-1014.

54. Peterson PK, Molitor TW, Chao CC (1998) The opioid-cytokine connection. Journal of Neuroimmunology 83, 63-69.

55. Przewlocki R, Hassan AHS, Lason W, Epplen C, Herz A, Stein C (1992) Gene expression and localization of opioid peptides in immune cells of inflamed tissue: functional role in antinociception. Neuroscience 48, 491-500.

56. Puttick RM (1992) Excitatory action of prostaglandin $E_{2}$ on rat neonatal cultured dorsal root ganglion cells. Bri J Pharmacol 105, 133 P.

57. Rios L, Jacob JJC (1982) Inhibition of inflammatory pain by naloxone and its Nmethyl quaternary analogue. Life Science 31, 1209-12.

58. Rosen H, Behar O, Abramsky O, Ovadia H (1989) Regulated expression of proenkephalin A in normal lymphocytes. J Immunology 143, 3703-3707.

59. Rubinstein M, Mogil JS, Japon M, Chan EC, Allen RG, Low MJ (1996) Absence of opioid stress-induced analgesia in mice lacking $\beta$-endorphin by site-directed mutagenesis. Proc Natl Acad Sci 93, 3995-4000.

60. Rueff A, Dray A (1992) 5-hydroxytryptamine-induced sensitization and activation of peripheral fibers in the neonatal rat are mediated via different 5-hydroxytryptamine receptors. Neuroscience 50, 899-905.

61. Russell NJW, Schaible HG, Schmidt RF (1987) Opiates inhibit the discharges of fine afferent units from inflamed knee joint of the cat. Neuroscience Letters 76, 107-112.

62. Sacerdote P, Bianchi M, Riccardi-Castagnoli P, Panerai A (1992) Tumor necrosis factor alpha and interleukin-1 alpha increase pain thresholds in the rat. Ann NY Acad Sci 650, 197-201. 
63. Schafer M, Carter L, Stein C (1994) Interleukin $1 \beta$ and corticotropin-releasing factor inhibit pain by releasing opioids from immune cells in inflamed tissue. Proc Natl Acad Sci 91, 4219-4223.

64. Scheller RH, and Hall ZW (1992) Chemical messengers at synapses. In: An Introduction to Molecular Neurobiology, Zach W. Hall (ed) Sinauer Associates, Inc., Sunderland, Massachusetts, p. 137.

65. Schroeder JE, Fischbach PS, Zheng D, McCleskey EW (1991) Activation of mu opioid receptors inhibits transient high-and low-threshold $\mathrm{Ca}_{2}{ }^{+}$currents, but spares a sustained current. Neuron 6, 13-20.

66. Schweizer A, Feige U, Fontana A, Muller K, Dinarello CA (1988) Interleukin-1 enhances pain reflexes. Mediation through increased prostaglandin $\mathrm{E}_{2}$ levels. Agents and Action 25, 246-251.

67. Selley DE, Breivogel CS, Childers SR (1993) Modification of G protein-coupled functions by low $\mathrm{pH}$ pretreatment of membranes from NG-108-15 cells increase in opioid agonist effiicacy by decreased in-activation of $\mathrm{G}$ proteins. Mol Pharmacol 44, 731-741.

68. Shearman M S, Sekiguchi K, Nishizuka Y (1989) Modulation of ion channel activity: a key function of the protein kinase $\mathrm{C}$ enzyme family. Pharmacological Reviews 41, 211-237.

69. Shepherd GM (1988) The Somatic Senses. In: Neurobiology, Gordon M. Shepherd (ed) Oxford University Press, New York, pp. 247-269.

70. Simon EJ, Hiller JM (1988) Solubilization and Purification of Opioid Binding Sites. In: The Opiate Receptors, Gavril W. Pasternak (ed) The Humana Press, Clifton, pp.165189.

71. Simon EJ, Hiller JM, Edelman I (1973) Stereospecific binding of the potent narcotic analgesic [3H] etorphine to rat brain homogenate. Proc Natl Acad Sci 70, 1947-1949.

72. Smith EM, Morril AC, Meyer WJ, Blalock JE (1986) Corticotropin releasing factor induction of leukocyte-derived immunoreactive ACTH and endorphins. Nature 321, 881-882.

73. Smith TW, Buchan P, Parsons DN, Wilkinson S (1982) Peripheral antinociceptive effects of N-methyl morphine. Life Science 31, 1205-08. 
74. Stein C, Millan MJ, Shippenberg TS, Peter K, Herz A (1989) Peripheral opioid receptors mediating antinociception in inflammation. Evidence for involvement of $\mathrm{Mu}$, Delta and Kappa receptors. J Pharmacol Exp Ther 248, 1269-1275.

75. Stein, C (1993) Peripheral mechanisms of opioid analgesia. Anesth Analg 76, 182-191.

76. Stein C, (1995) The control of pain in peripheral tissue by opioids. The New England Journal of Medicine 332(25), 1685-1690.

77. Stein C, Comisel K, Haimerl E, Yassouridis A, Lehrberger K, Herz A, Peter K (1991) Analgesic effect of intraarticular morphine after arthroscopic knee surgery. The New England Journal of Medicine 325(16), 1123-1126.

78. Stein C, Gramsch C, Herz A (1990) Intrinsic mechanisms of antinociception in inflammation: local opioid receptors and $\beta$-endorphin. $J$ Neuroscience 10, 1292-1298.

79. Stein C, Hassan AHS, Przewlocki R, Gramsch C, Peter K, Herz A (1990) Opioids from immunocytes interact with receptors on sensory nerves to inhibit nociception in inflammation. Proc Natl Acad Sci 87, 5935-5939.

80. Stein C, Hassan A, Lehrberger K, Giefing J, Yassouridis A (1993) Local analgesic effect of endogenous opioid peptides. The Lancet 342, 321-324.

81. Stein C, Pfluger M, Yassouridis A, Hoelzl J, Lehrberger K, Welte C (1996) No tolerance to peripheral morphine analgesia in presence of opioid expression in inflamed synovia. J Clinical Investigations 98(3), 793-799.

82. Steranka RR, Manning D, DeHass CJ, Ferkany JW, Borosky SA, Connor JR, Vavrek RJ, Stewart JM, Snyder SH (1988) Bradykinin as a pain mediator: receptors are localised to sensory neurones and antagonists have analgesic action. Proc Natl Acad Sci 85, 3245-3249.

83. Taiwo YO, Levine JD (1991) $\kappa$-and $\delta$-opioids block sympathetically dependent hyperalgesia. J of Neuroscience 11, 928-932.

84. Taiwo YO, Levine JD (1992) Serotonin is a directly-acting hyperalgesic agent in the rat. Neuroscience $\mathbf{4 8}, 485-590$.

85. Terenius, L (1973) Specific uptake of naroctic analgesics by subcellular fractions of the guinea-pig ileum. Acta Pharmacologica Tox. 31, Suppl I, 50.

86. Thayer SA, Perney TM, Miller RJ (1988) Regulation of calcium homeostasis in sensory neurons by bradykinin. Journal of Neuroscience 8: 4089-4097. 
87. Werz MA, MacDonald RL (1983) Opioid peptides selective for mu- and delta-opiate receptors reduce calcium-dependent action potential duration by increasing potassium conductance. Neuroscience Letters 42, 173-178.

88. Yaksh TL (1988) Substance P release from knee joint afferent terminals: modulation by opioids. Brain Research 458, 319-324.

89. Yaksh TL, Jessell TM, Gamse R, Mudge AW, Leeman SE (1980) Intrathecal morphine inhibits substance $\mathrm{P}$ release from mammalian spinal cord in vivo. Nature 286, 155-157.

90. Yasuda K, Raynor K, Kong H, Breder CD, Takeda J, Reisine T, Bell GI (1993) Cloning and functional comparison of $\kappa$ and $\delta$ opioid receptors from mouse brain. Proc Natl Acad Sci 90, 6736-6740.

91. Young WS, Wamsley JK, Zarbin MA, Kuhar MJ (1980) Opioid receptors undergo axonal flow. Science 210, 75-77. 